\title{
CO-LIVING PRACTICES OF YOUNG AND ELDERLY FROM THE PERSPECTIVE OF SOCIAL SUSTAINABILITY- m:u:t:u:a:I ${ }^{1}$
}

\section{GENÇ VE YAŞLI BİREYLERIIN SOSYAL SÜRDÜRÜLEBİLİRLİK BAĞLAMINDA ORTAK YAŞAM PRATIKLLERİ- m:u:t:u:a:I}

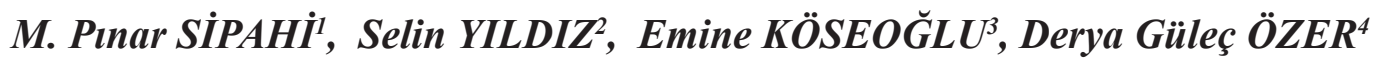

1-2-4 Yildız Technical University, Faculty of Architecture, Department of Architecture, İstanbul / Turkey

${ }^{3}$ Fatih Sultan Mehmet Vakif University, Faculty of Architecture and Design, Department of Architecture,

Istanbul / Turkey

ORCID ID: 0000-0001-6076-6989', 0000-0001-6913-6940², 0000-0003-2457-7659², 0000-0003-0288-87714

Öz: Amaç: Bu çalışma üniversite öğrencileri ve yalnız yaşayan tek hane halkları arasında, hayatta kalma mücadelesine bağlı temel gereksinimleri firsata dönüştüren bir ortak yaşama modelini araştırmaktadır. Hızla değişen kent yaşamı ile mücadele eden bireyler, sosyal sürdürülebilirliğin barınma, bulușma ve bir araya gelme pratiklerine odaklanacaklardır. Yöntem: Bu çalıșma kapsamında paylaşım ekonomisi; sosyal, psikolojik ve mimarlık konuları açısından ele alınacaktır. Bu çerçevede, önerilen m:u:t:ua:l ortak yaşam modeli, yalnız yaşayan yaşlı bireylerle barınma gereksinimini karșılayacak ekonomik güçte olmayan öğrencileri bir araya getirmeyi amaçlamaktadır. Bulgular: Bu çalışmada öncelikle, Beşiktaş bölgesindeki yurt kapasiteleri ve üniversitelerin öğrenci sayıları belirlenerek karșılaștırılmıștır. Sonrasında, modelin gelliștirildiği ve desteklendiği üniversitede (XXX) 214 mimarlık bölümü öğrencisi ile anket yapılmıştır. Ek olarak, modele dair görüşlerini almak amacıyla yaşılı bireylerle görüşmeler gerçekleştirilmiștir. Tüm bu ölçümler, modelin test edilmesi anlamında bir ön çalışmayı oluşturmaktadır. Sonuç: Yurt kapasiteleri ile öğrenci sayıları arasında yapılan karşılaştırma, konaklama mekanlarının yetersizliğini göstermiş̧tir. Üniversite öğrencileri ile yapılan anket çalışması ile elde edilen sonuclar, gençlerin modele olumlu yaklaștığını göstermisțir. Öte yandan yaşlı bireyler, bu türden bir yaşama modeli içinde bulunabileceklerini belirtirken ihtiyatlı davranmışlardır. İki nesli bulușturan bu modelin, ekonomik açıdan sağlayacağı faydanın ötesinde, nesillerin birlikteliği ve bireylerin yaşam kalitesinin artması bağlamında toplumsal sürdürülebilirliğe katkısı hedeflenmektedir.

Anahtar Kelimeler: Ortak Yaşam, Paylaşım Ekonomisi, Yaşlı, Genç, Sosyal Sürdürülebilirlik
Abstract: Aim: This study investigates the potentials of a co-living model between university students and the elderly living alone that turns survival paradigm into an opportunity. The individuals who struggle in the changing and accelerating urban life are focused in terms of housing, meeting and gathering practices of social sustainability. Method: In this study, the concept of sharing economy, social, psychological and architectural frameworks are discussed through this context. Within this framework, the proposed m:u:t:u:a:l model brings together elderly homeowners who need to share their loneliness with students who cannot afford the rent but have priceless time to share with someone. This m:u:t:u:a:l model is developed as a pilot study and supported within a university $(\mathrm{XXX})$ where a list of survey questions are asked to 214 architecture students, and findings are presented. On the other hand, research questions are also asked to elderly people to determine their point of view to this study. In addition, the capacities of dormitories and the number of university students within Besiktas District are determined. These measurements constitute a preliminary study to test the m:u:tu:a:l model. Results: The results of the analyses are supported and discussed by spatial and numerical data of survey questions and include findings of the young-elderly co-living potential of the region of Beşiktaş/ İstanbul. Conclusion: The comparison of the capacities of dormitories and the number of students reveal the inadequacy of accommodation facilities for university students. Furthermore, the results of the questionnaire show that most of the university students seem to welcome the idea of living with elderly individuals. Elderly's answers reveal their deliberation towards system. It is envisaged to conduct further site studies and survey researches to test the applicability of the m:u:t:u:a:l model. With this model, it is concluded to contribute to the social sustainability in terms of coexistence of generations and individual life quality beyond economic utilitarianism.

Key Words: Co-living, Sharing Economy, Elderly, Youth, Social Sustainability

Doi: $10.17365 /$ TMD.2018.3.9

(1) Sorumlu Yazar: M. Pınar SiPAHI, Yuldz Technical University, Faculty of Architecture, Department of Architecture, İstanbul/Turkey,psipahi@yildizedu.tr, Geliş Tarihi/Received: 17.10.2018, Kabul Tarihi/Accepted: 11.12.2018 Makalenin Türü: Type of article (Araştırma - Inceleme / Research Examination) Çıkar Çatışması - Conflict of Interest: Yok / None “Etik Kurul Raporu Yok-None of Ethics Commit 


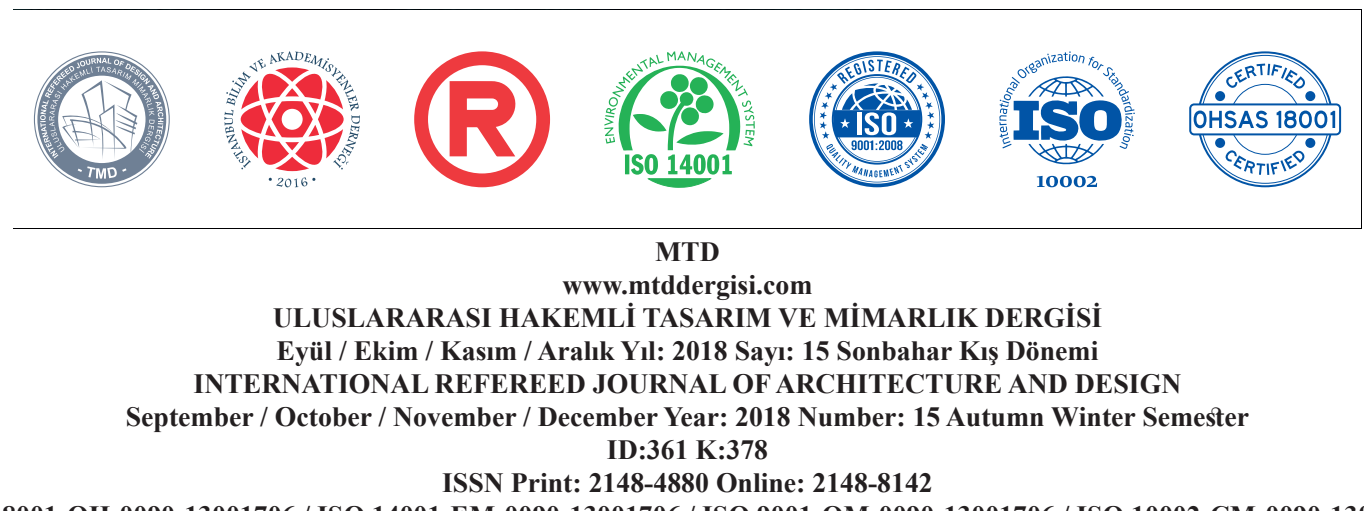

ISSN Print: 2148-4880 Online: 2148-8142

(ISO 18001-OH-0090-13001706 / ISO 14001-EM-0090-13001706 / ISO 9001-QM-0090-13001706 / ISO 10002-CM-0090-13001706)

(Marka Patent No / Trademark)

$(2015 / 04018-2015 / G E / 17595)$

space where individuals can freely carry out their habits, daily routines or embrace their aesthetic values while being provided with basic physical needs, physical and inner safety, social needs such as "acceptance and appreciation by others, friendship, to love and being loved" and mutual respect, a home is a place where one can lead a good life directed towards self-actualization. Therefore, this study while presenting an alternative model covering the co-living practices of young and elderly individuals aims to measure the potentials to get realized through a preliminary case study which is conducted in Besiktas District in Istanbul.

\section{RESEARCH PROBLEM}

Based on Maslow's hierarchy of needs, young individuals who have left their family homes to pursue higher education seek to meet their most basic need: Shelter. When seeking accommodation, young individuals are facing several difficulties that are disruptive to the quality of daily life because of their limited financial resources (Figure 2).

As for the second subject of m:u:t:u:a:1 coliving model, elderly individuals living alone in areas near universities, may meet their basic physical needs in their own homes yet fail to meet their psychological needs due to increasing social isolation and loneliness. Even though the lack of psychological satisfaction does not pose a vital threat to elderly individuals' lives, they may, however, damage the fulfillment of their physical needs. More precisely, isolation and loneliness may trigger depression, often accompanied by poor eating habits and resulting in malnutrition, inactivity, weakened communication skills and loss of joy of life.

To meet their accommodation needs, students have to;

- Pay exorbitant rents for accommodation near universities

- Split the exorbitant rents and bills with housemates for housing near Universities, which leads to a decrease in the quality of life

- Pay affordable rents for housing in remote areas, but waste valuable time, energy and concentration for transport.

Although the abovementioned solutions meet the physical needs of students, they may cause them to face a variety of problems in relation to different physical and psychological needs. The problems can be listed as; waste of time, waste of energy, unsanitary environments, lack of focus and concentration, malnutrition, lack of adequate space and equipment, crowded environments, inadequate security, lack of a sense of belonging/ownership. 

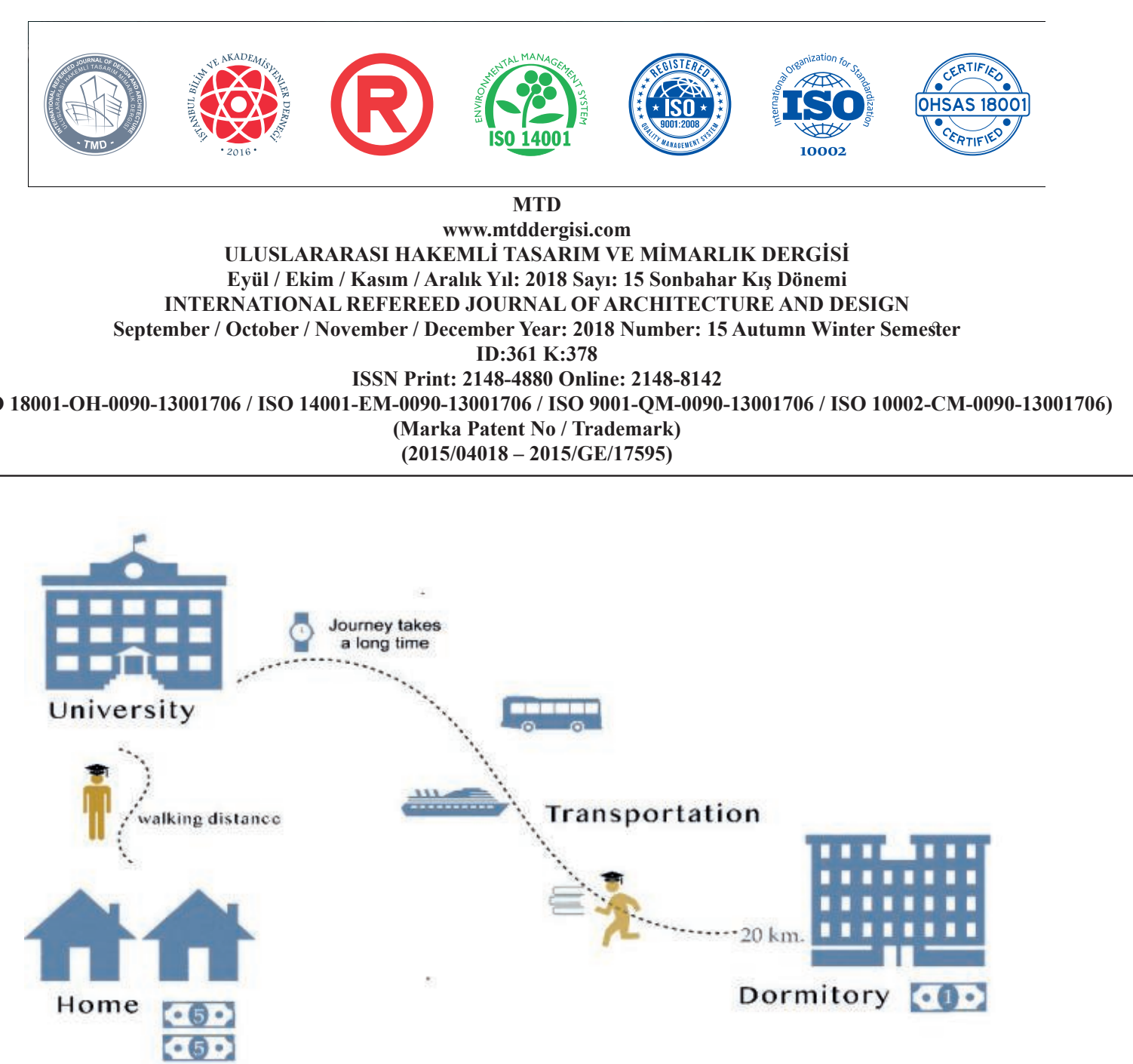

Figure 2. School-accommodation Relationships for University Students

The m:u:t:u:a:1 presented in this study suggests a scientific and conceptual identification of real persons' needs, and suggests to meet these needs in the most interactive way possible. According to the m:u:t:u:a:1, a center should be established to monitor and manage the system. The trust mechanism of the system will be established within the university as a central reputation stakeholder. The university is the mechanism by which the host can communicate with the student and vice versa. For security, methods such as identification documents, passport information, transcripts, written agreements, reference letters, ratings, etc. establish mutual trust systems. The model should:
- Identify the subjects' potential resources and needs, create an information center,

- Find the right match through personality tests and physical analyses supported by specialist psychologists,

- Identify the lack of space and take the appropriate actions to provide more space,

- Ensure that students submit rent on time,

- Ensure the continuity and improvement of the system by providing feedback and offering reviews after the process is completed. 


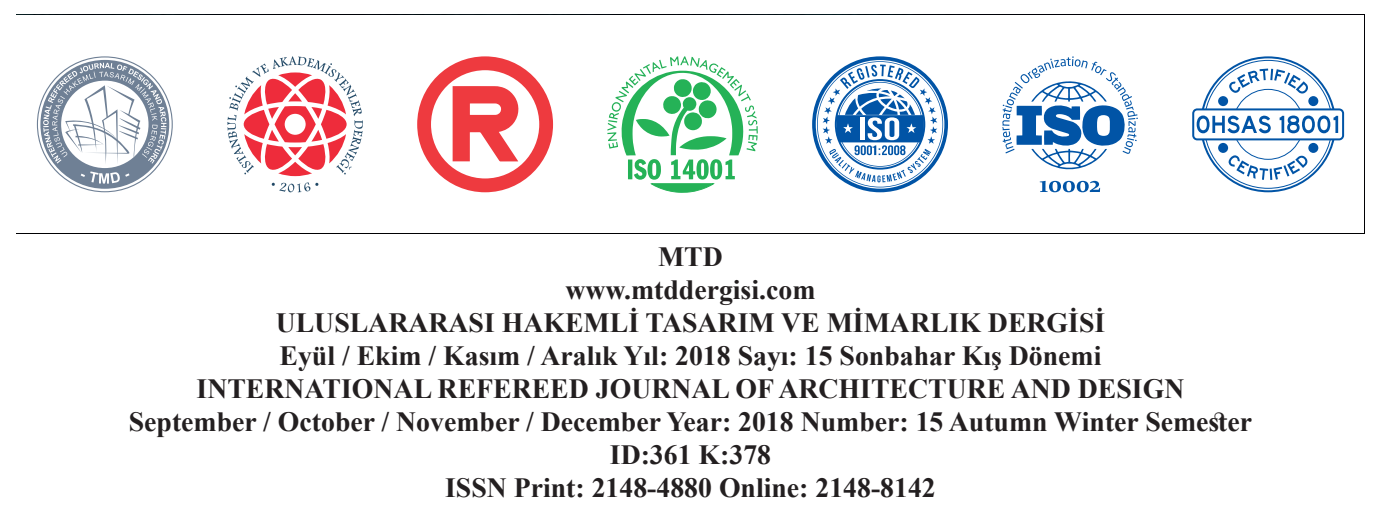

(ISO 18001-OH-0090-13001706 / ISO 14001-EM-0090-13001706 / ISO 9001-QM-0090-13001706 / ISO 10002-CM-0090-13001706)

(Marka Patent No / Trademark)

$(2015 / 04018-2015 / G E / 17595)$

\section{THEORETICAL FRAME}

\section{The Idea of Sustainable Development, So- cial Sustainability and Space}

Many new developments, that started to occur several decades after the Industrial Revolution, particularly with the emergence of environmental concerns in the early 20th century, have significantly contributed to the spread of sustainable development ideas. The increase in the number of studies and approaches focusing on the human impact on the environment and vice versa since the 1950 s can be considered as an essential milestone in motivating people towards sustainability. Notably, designed to monitor and even foresee the negative effects of industrialization as well as the signs and symptoms of globalization following the World War II, the first environmental movement, the first wave of environmentalism, has surfaced in the 1960s and 1970s. Issued within this context in 1972, the "Limits to Growth" report by the MIT research team focused on uncontrolled growth and limited resources (Ekins, 1993: 269; Yeni, 2014: 184).
Different sources, arguing that the idea of sustainable development should be implemented as a solution perspective in overcoming environmental issues, present different justifications. For instance, Yeni (Yeni, 2014: 184) points out that the fundamentals of the sustainable development phenomenon are based on the World Conservation Strategy report published in 1980 and prepared by the International Union for Conservation of Nature and Natural Resources (IUCN). On the other hand, the notion of sustainable development was first popularised in the report "Our Common Future", also called Brundtland Report, released in 1987 by the World Commission on Environment and Development (WCED) (Holden et al., 2014: 131; Langhelle, 1999: 130) (Figure 3). Gürel Üçer (Gürel Üçer, 2017: 105) points out that the report includes a definition of sustainable development: "Development which meets the needs of the present without compromising the ability of future generations to meet their own needs". In time, however, this report would be deemed a traditional approach to the problem due to its absence of consideration of essential elements (Seghezzo, 2009: 541). 


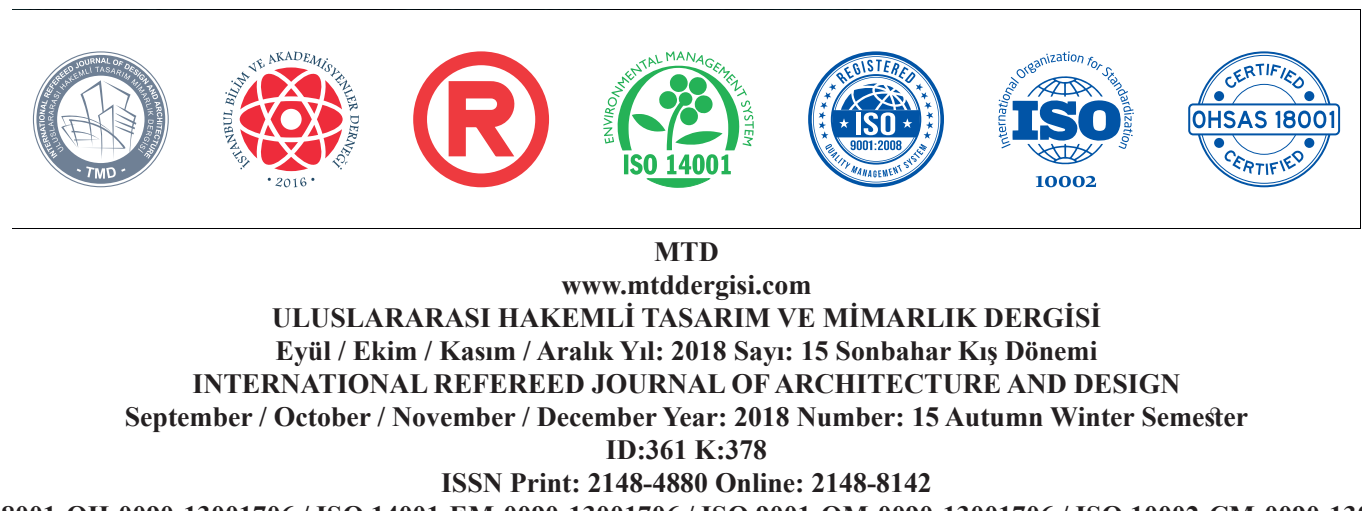

ISSN Print: 2148-4880 Online: 2148-8142

(ISO 18001-OH-0090-13001706 / ISO 14001-EM-0090-13001706 / ISO 9001-QM-0090-13001706 / ISO 10002-CM-0090-13001706)

(Marka Patent No / Trademark)

$(2015 / 04018-2015 / G E / 17595)$
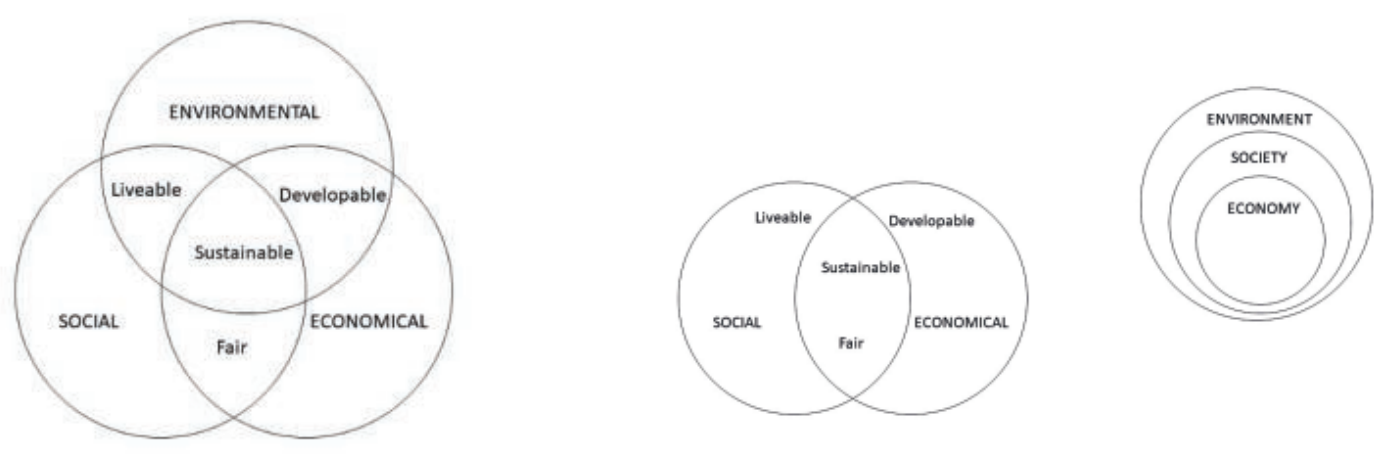

Figure 4. (left) Three Dimensions of Sustainable Development - Classic Venn Diagram

Model (right) Russian doll / Matryoshka Model / Embedded Model (Gürel Üçer, 2017:

108)
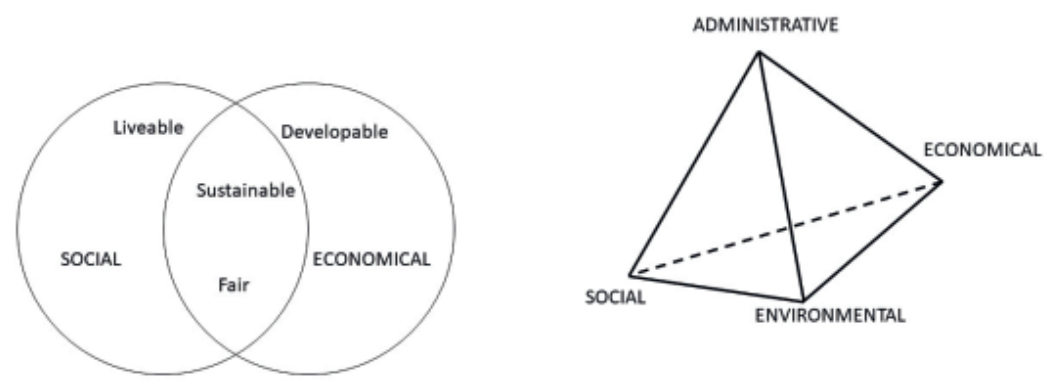

\section{Figure 5. Four Dimensions of Sustainable Development - Prism Model}

(Gürel Üçer, 2017: 108)

According to the United Nations 2014 report, $54 \%$ of the world's population lives in urban areas, a proportion that is expected to increase to $66 \%$ by $2050^{1}$. Shaped and influenced by the effects of globalization trends, most of the cities today attract people as centers of innovation, production, cultural diversity,

1 United Nations 2014 Report on world population: https://esa.un.org/unpd/wup/ physical and social infrastructure. However, rapidly growing urban population and inadequately managed urban expansion lead to the inefficient use of natural resources and physical infrastructure, declining levels of sharing as well as social and individual waste of energy, all of which, in result, not only affects negatively individual health but also brings cumulative health risks. In terms of 


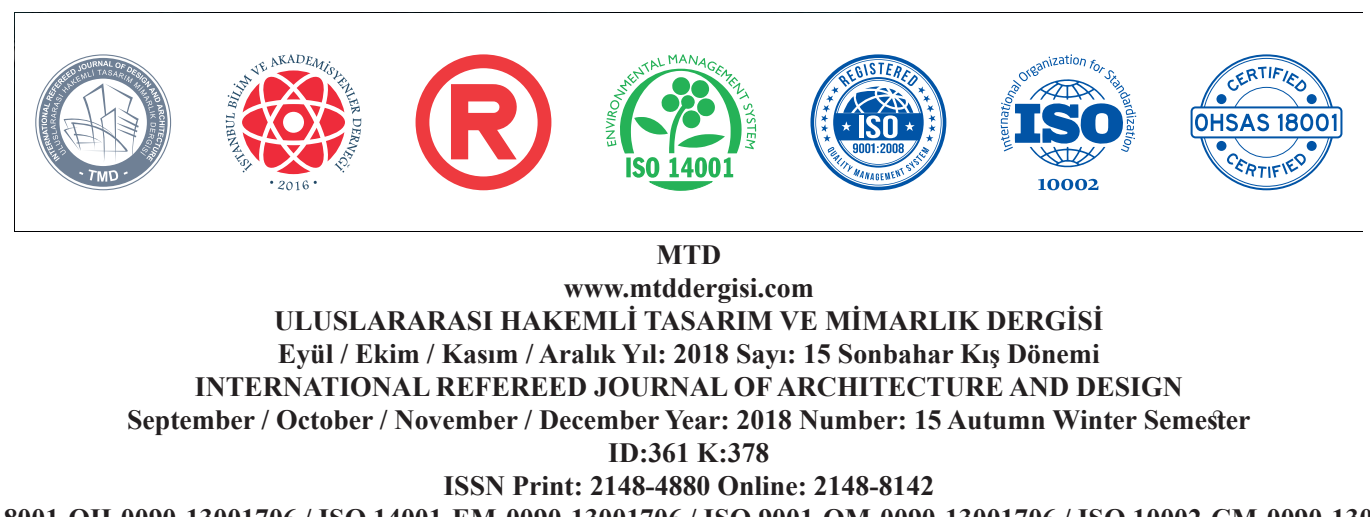

ISSN Print: 2148-4880 Online: 2148-8142

(ISO 18001-OH-0090-13001706 / ISO 14001-EM-0090-13001706 / ISO 9001-QM-0090-13001706 / ISO 10002-CM-0090-13001706)

(Marka Patent No / Trademark)

$(2015 / 04018-2015 /$ GE/17595)

ensuring the sustainability of social life, the social sustainability indicators will serve as a basis for the creation of co-living spaces considering the physical, spatial and cultural data as well as related possibilities they can offer, especially for the housing needs.

The administrative aspect of sustainability should focus on designing urban housing models that are capable of improving social communication and interaction while contributing to less social isolation and more transfer of social life experience between generations. One of these urban housing models, which will be explained in details in the following parts of this study, covers the possibility of people in different age groups (young and elderly individuals) to share a house, associated with "sharing economy" system, therefore share the life, experiences, and values.

\section{The Sharing Economy and Housing Phe- nomenon}

Sustainability concerns/ policies/ indicators have almost always embraced and supported the ways to reduce our carbon footprint, efficient use of natural resources and social involvement or participation as an important instrument to help realize these goals (Cengiz et al., 2014: 24; Kessler, 1992: 92). Sharing economy platforms gradually become one of the inputs of sustainability, which, as a main component of "green economy", enables the human, time, space, commodity, energy, labor and product-scale utilization of existing resources (Figure 5).

Sharing economy is defined as a concept that highlights the ability of individuals or institutions to take the activities that consume the available capacity under control in order to ensure efficient use/consumption of natural resources. Different types of sharing economy are categorized as follows: Profit-driven sharing: Marketing, leasing, barter activities are considered to be amongst this type of sharing. Accordingly Airbnb, EBay, Uber and Zipcar are considered to be amongst many sharing platforms that are profit-driven. Social entrepreneurship / cooperatives: Although this type of sharing economy has great similarities with profit-driven sharing, it differs from the former in terms of motivation, unlike the way it is practiced. It involves social or environmental objectives and targets rather than profit motives. Non-profit driven sharing: Environments where entrepreneurs do not seek any profit in order to carry on their missions. Social sharing: It focuses on local or neighbourhood-scale sharing. The motive in social sharing is to improve and enhance social human relations/interactions. Public space-scale sharing: This type of sharing involves highly organized, arranged structures 


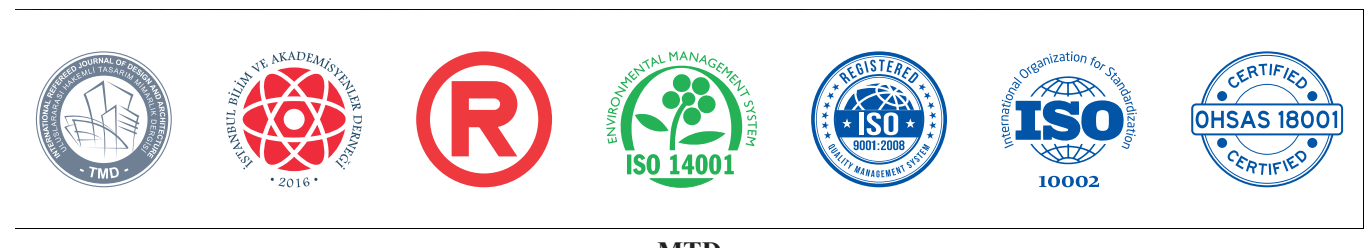

www.mtddergisi.com

ULUSLARARASI HAKEMLİ TASARIM VE MIMMARLIK DERGİSI

Eyül / Ekim / Kasım / Aralık Yıl: 2018 Sayı: 15 Sonbahar Kış Dönemi

INTERNATIONAL REFEREED JOURNAL OF ARCHITECTURE AND DESIGN

September / October / November / December Year: 2018 Number: 15 Autumn Winter Semester ID:361 K:378

ISSN Print: 2148-4880 Online: 2148-8142

(ISO 18001-OH-0090-13001706 / ISO 14001-EM-0090-13001706 / ISO 9001-QM-0090-13001706 / ISO 10002-CM-0090-13001706)

(Marka Patent No / Trademark)

$(2015 / 04018-2015 / G E / 17595)$

in a systematic, orderly way such as public libraries. $^{2}$

Sharing economy offered alternative ways to maintain a certain standard of living and chosen lifestyles. ${ }^{3}$ Although initially caused by economic reasons, the above-mentioned

2 http://www.ukayamut.com/wp-content/ uploads/2016/02/the-sharing-economy-andsustainability-feb-7-2016.pdf

3 http://www.ukayamut.com/wp-content/ uploads/2016/02/the-sharing-economy-andsustainability-feb-7-2016.pdf sharing activities have also helped urban populations develop a stronger sense of belonging/ownership, reduce social isolation and loneliness, therefore improve physical, mental, emotional and social well-being since these activities significantly enable social interaction, sharing, togetherness, connection and communication, and these types of human interaction are carried out through newly "invented or devised" alternatives methods in lieu of conventional, routine and outdated ones (Table 1). 


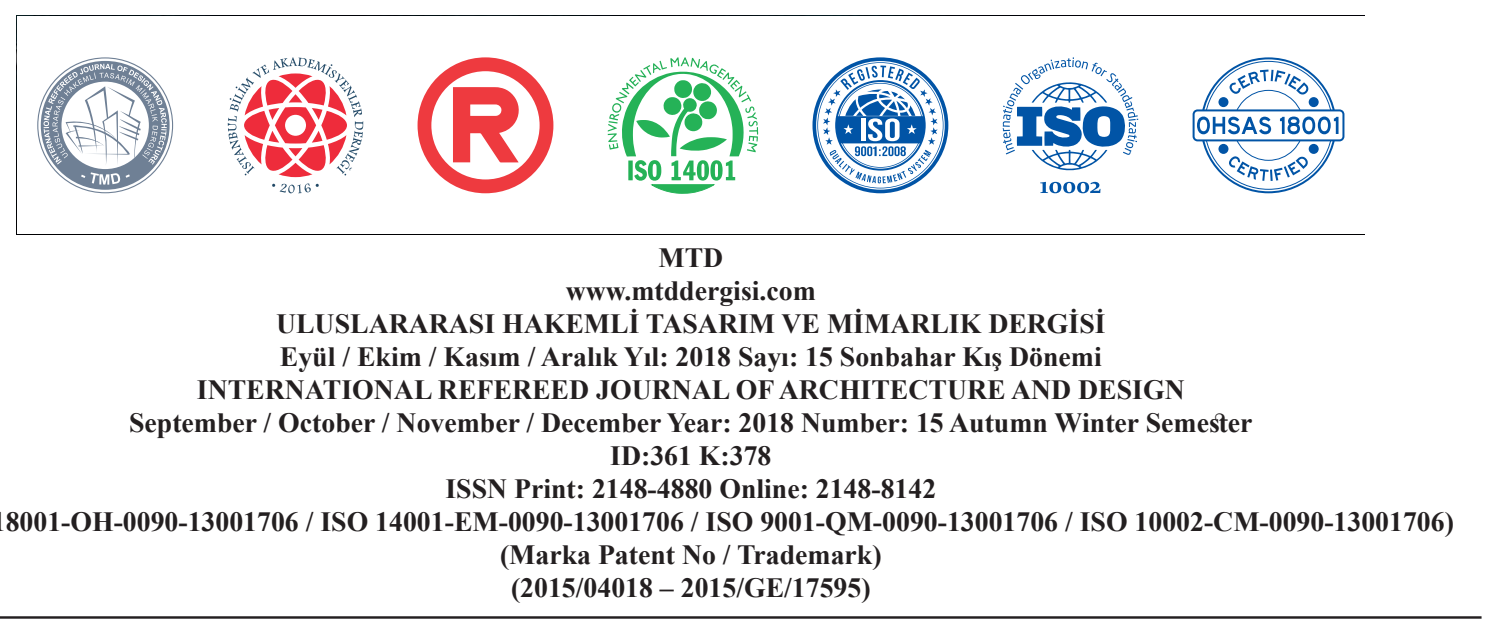

\begin{tabular}{c} 
(ISO 18001-OH-0090-13001706 / ISO 14001-EM-0090-13001706 / ISO 9001-QM-0090-13001706 / ISO 10002-CM-0090-13001706) \\
(Marka Patent No / Trademark) \\
$(2015 / 04018-2015 / G E / 17595)$ \\
\hline
\end{tabular}

\section{Table 1. Sharing Economy Practices}

Co-working Social networks, such as CitizenSpace, Hub Culture and The Hub, provide a common working environment for both working and social work.

It covers different units and alternative currencies used instead of money. Time banks

Social Money that use time instead of money; alternative currencies such as Quid, Ven; credit units such as LETSystems are examples of social money. In Turkey, Zumbara, where time is used instead of money; is a community where talents and experiences are shared.

Taxi Sharing A taxi is used by more than one person. There are samples like Taxi2, TaxiStop.

Barter

It means exchange. The websites like Barterquest and OurGood allow you to exchange services, skills and goods.

Garden Sharing

Websites that bring together the people who own the garden and the people who have knowledge about the garden work or provides the common garden usage.

Ability Sharing

It enables people to teach each other their skills and skills. People share skills through websites such as Brooklyn Skill Share, TeachStreet and TradeSchool.

Mass Funding

It is the use of the Internet in order to get the necessary financial support for various projects and campaigns. Although Indiegogo and Kickstarter very well known, Projemefon is an example of the mass funding from Turkey.

Social Meal Networks

Gooble, a neighbor serving food to the neighbor; EatWithMe that provide to eat together; GrubWithUs with the "Never eat alone" motto are established to share the dining experience.

Parking Dots

Neighborhood Support

On websites such as Parkatmyhouse, people can rent the parking lot of their homes to other people or rent a parking space from other houses.

Websites such as WeCommune and StreetBank have been created in order to enable people in a certain environment to meet and support each other.

Travel from-oneto-one

It is the website that provides services such as being a guest in a person's home or renting a room. The most popular are CouchSurfing and Airbnb. It is possible to use the "EvDeğişTokuşu" from Turkey.

Today, supported mainly by social media and mobile devices as important communication and notifications platforms, the "sharing economy practices" are creating "synergetic environments" where individuals sell, barter or give away the assets, skills, information or places they own, including for example hosting a "Permablitz" which involves a group of people meeting up for the day to create edible gardens where someone lives or turning their homes into pop-up restaurants where they cook and offer foods at affordable prices. Additionally, in this long-time embraced model, as an alternative solution to the increasing isolation of humans from the natural world, where garden areas located in the pe- 


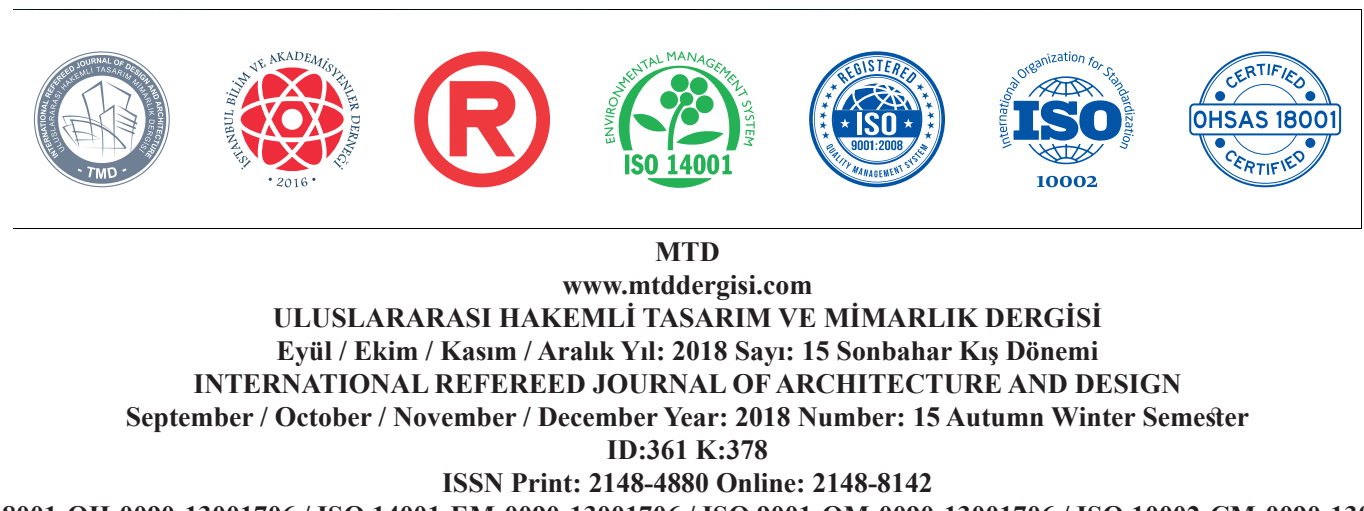

ISSN Print: 2148-4880 Online: 2148-8142

(ISO 18001-OH-0090-13001706 / ISO 14001-EM-0090-13001706 / ISO 9001-QM-0090-13001706 / ISO 10002-CM-0090-13001706)

(Marka Patent No / Trademark)

$(2015 / 04018-2015 / G E / 17595)$

ripheries of large cities are for daily, monthly or seasonal rent; and where the garden care, sowing/ planting/ harvesting activities serve as an outdoor "recreation" for the person(s) who rent these garden areas, the renter may also share some of the crops and products with the garden owner. Besides that, book swap for bibliophiles; sharing, swapping or exchange of clothes or any used, no-longerneeded items as well as online or face-to-face “open school", “open learning”, “open courses" activities to enhance knowledge sharing are considered as a part of sharing economy practices (Demirer, Hasan, 2016: 47) (Figure 6)

Among the above-mentioned practices, we may cite other examples that are closely correlated with physical space and accommodation, including renting your empty house temporarily while you travel or paying to stay in someone's home rather than in a hotel. One of the earliest forms of peer-to-peer accommodation included the "au pair" program where students studying abroad stay with a host family while host families benefit from affordable childcare.

\section{Co-Living Practices in the World}

The sharing economy in international societies has started to create socio-economic ecosystems due to a variety of factors including changing economic conditions, con- sumption habits, aging populations and cultural diversity. The sharing activities among individuals with different demographic characteristics take place in "houses". Hence, the interfaces of sharing practices with accommodation sector at significant destinations have been focused in this chapter. Most companies and websites are involved as major actors in the housing sharing sector. However, in our country, the leading representatives of this sector, which can be considered as new, appear as social sharing platforms and housemate sites and produce unregistered markets. In addition to this, the systems with this confidence gap are shaped according to the consumption habits and living conditions that vary according to the place and culture. In order to form a basis and lighten the proposal of this study which is intended to be implemented in large and dense cities, samples from worldwide locations (mostly cosmopolitan and with changing dynamics) are discussed. Below you will find a few examples of these activities that are currently being practiced in the USA, UK and other European countries under two titles: Design: Designs of innovative co-living units, Transformation: Shared use of existing living spaces.

Design: Offering independent yet highly interrelated living spaces where each unit can be rented separately, innovative co-living units are designed to be flexible so as to meet 


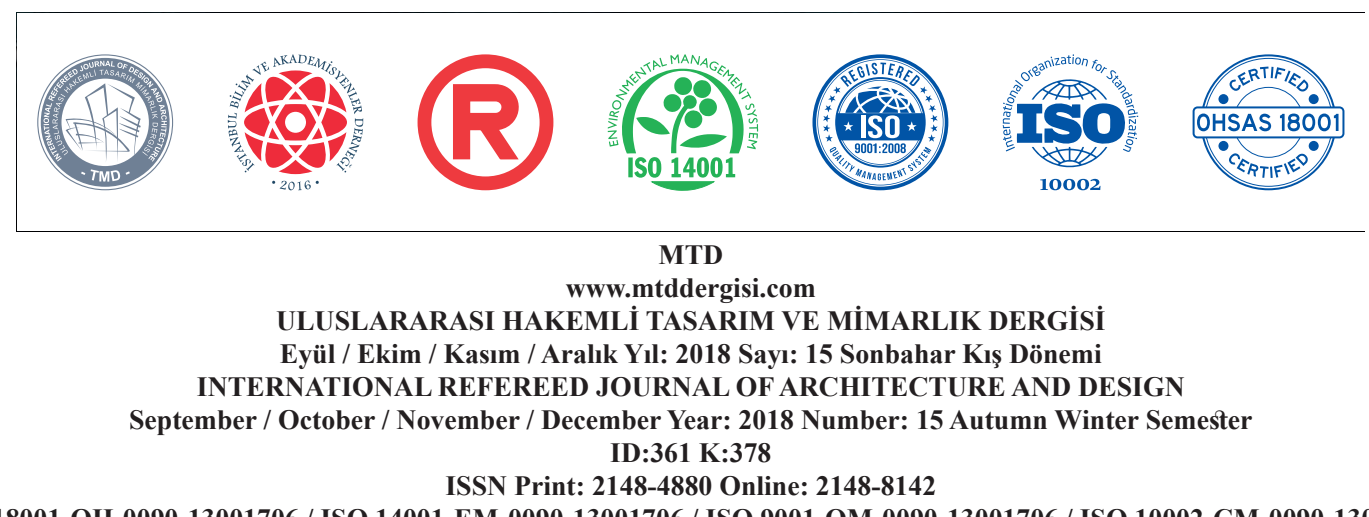

ISSN Print: 2148-4880 Online: 2148-8142

(ISO 18001-OH-0090-13001706 / ISO 14001-EM-0090-13001706 / ISO 9001-QM-0090-13001706 / ISO 10002-CM-0090-13001706)

(Marka Patent No / Trademark)

$(2015 / 04018-2015 /$ GE/17595)

different human needs including living, eating, self-care and hygiene, working, socializing and leisure. A flexible and experimental 1,000-square-foot home designed by architect Pierluigi Colombo for an exhibition in Washington, DC, the Open House features a hyper-efficient layout, multifunctional furniture and movable walls, allowing the space to satisfy the needs of a variety of today's growing but underserved households with different demographic characteristics. ${ }^{4}$ (Figure 6) His design is aimed at seeking solutions to a certain problem where fast-growing housing market has been slow to adapt to the unprecedented shifts in U.S. demographics and lifestyle.
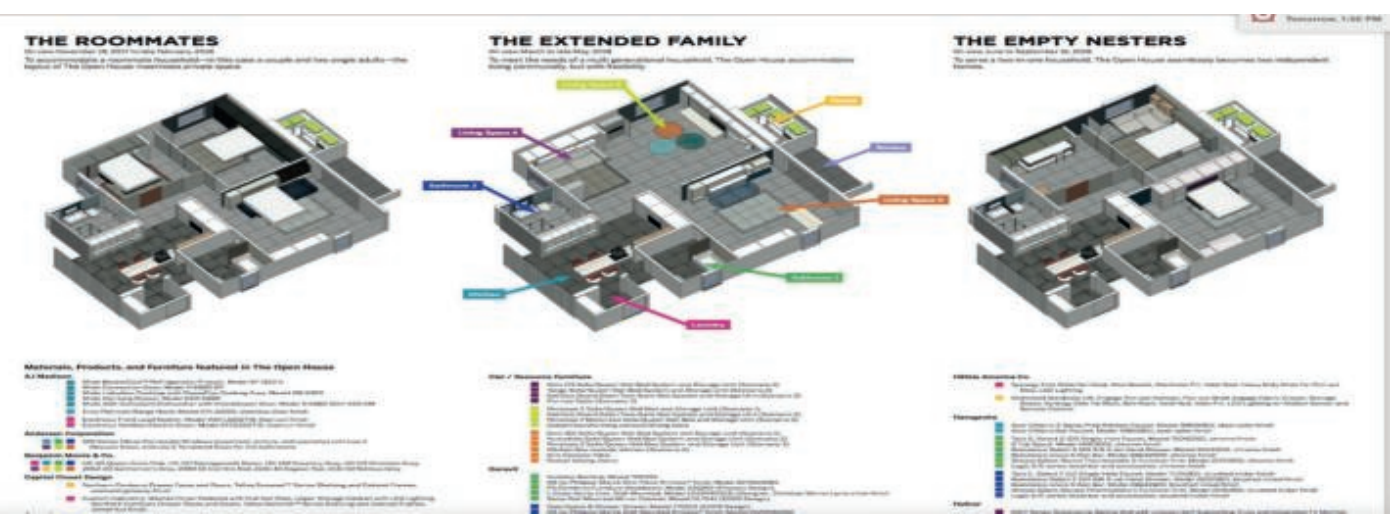

Figure 6. Co-Living Spaces (Architect Pierluigi Colombo, Open House) ${ }^{5}$

Just like the U.S. housing market, real estate sector in Turkey is also trying to offer alternative housing options, including micro-units or micro-apartments, large-scale housing production, to meet the needs of single-parent or extended families living in large cities. At this point, this does not seem as just a problem of household population growth, accordingly, the phenomenon of growing old at one place, at home should be focused on in terms of its effects on social security as well as individual and collective memory.

4 https://www.nbm.org/exhibition/making-room/
A partially built part of Colombo's experimental house exists in London under the name of "The Collective Old Oak" as the world's largest co-living start-up to satisfy the needs of a variety of today's growing households (Figure 7). Accordingly, people's demand for living in this building is rapidly increasing in order to turn urban loneliness into a more sharing and comfortable lifestyle. ${ }^{6}$ Stating that the starting point of the project is the fact that the changing housing
5 http://design-planning.blogspot.com.tr/2017/11/ exhibit-new-american-households.html
6 https://www.thecollective.co.uk/coliving




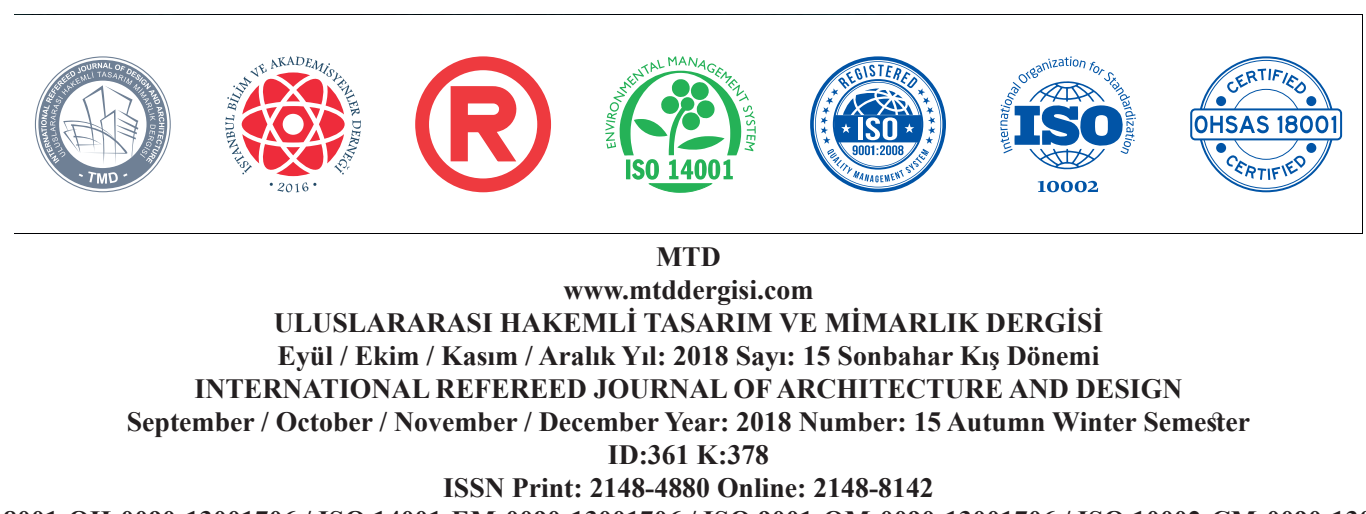

(ISO 18001-OH-0090-13001706 / ISO 14001-EM-0090-13001706 / ISO 9001-QM-0090-13001706 / ISO 10002-CM-0090-13001706)

(Marka Patent No / Trademark)

$(2015 / 04018-2015 / G E / 17595)$

needs of Generation Y is leading to a future where everyone is homeless, the entrepreneur behind the start-up James Scott says that socially liberated millennials are more likely to choose "living as a service", adding that the Collective especially appeals to millennials who have previously moved from adolescence into adulthood, thus taking their time to become socially liberated, experiment to find out what and who they love before committing to the adulthood. ${ }^{7}$

While dividing living spaces into different sections to save energy and physical space, the Old Oak also provides an opportunity to socialize with others. The house units including living room, bathroom, study room and kitchen are offered as shared or individual used facilities. All spaces within the building, except sleeping spaces, become 'shared'. Everything members need is included in bill; gym membership, cinema, sauna and spa, games room, roof terrace, daily events, all utilities, room cleaning and concierge.

\section{Transformation:}

Shared use of living spaces: Emerges as solutions aimed at providing social and economic benefits, which are to improve intergenerational communication and to provide a better environment of sharing and solidarity in nursing

7 https://www.dezeen.com/2016/07/15/in-thefuture-we-will-all-be-homeless-says-co-livingentrepreneur-the-collective-james-scott-housing/ homes or living spaces inhabited by individuals with different demographic characteristics.

Co-living model in nursing homes: In 2011, a Dutch nursing home launched a programme aimed at reducing loneliness and social isolation. ${ }^{8}$ The programme provides free rent to university students in exchange for a specified period of their time acting as neighbours with elderly residents (aged 80-90 and elderly). In accordance with their volunteer agreement, students spend time teaching residents new skills, including how to use internet, social media, and even graffiti art. They also donate their time to bring conversation, literature, and friendship to the residents. Research shows that reading poetry with dementia sufferers brings them comfort.

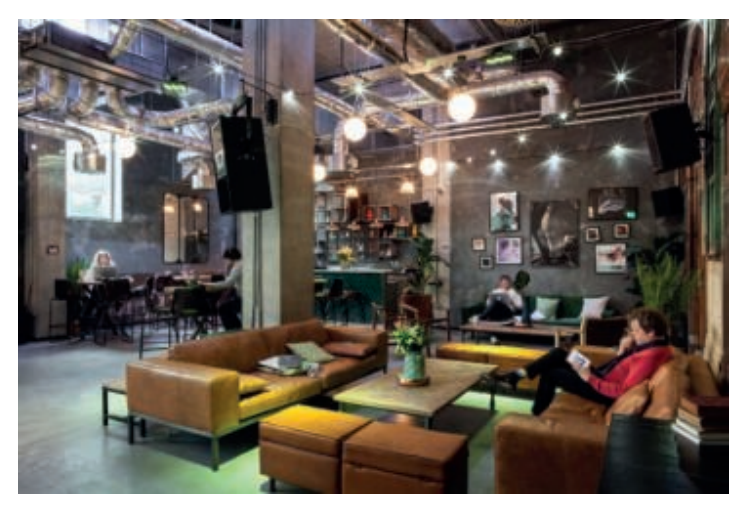

Figure 7. The Old Oak co-living space (London) ${ }^{9}$

8 https://www.independent.co.uk/life-style/ health-and-families/why-some-dutchuniversity-students-are-living-in-nursing-homesdemential-a7451486.html

9 https://www.headbox.com/spaces/6444-book- 


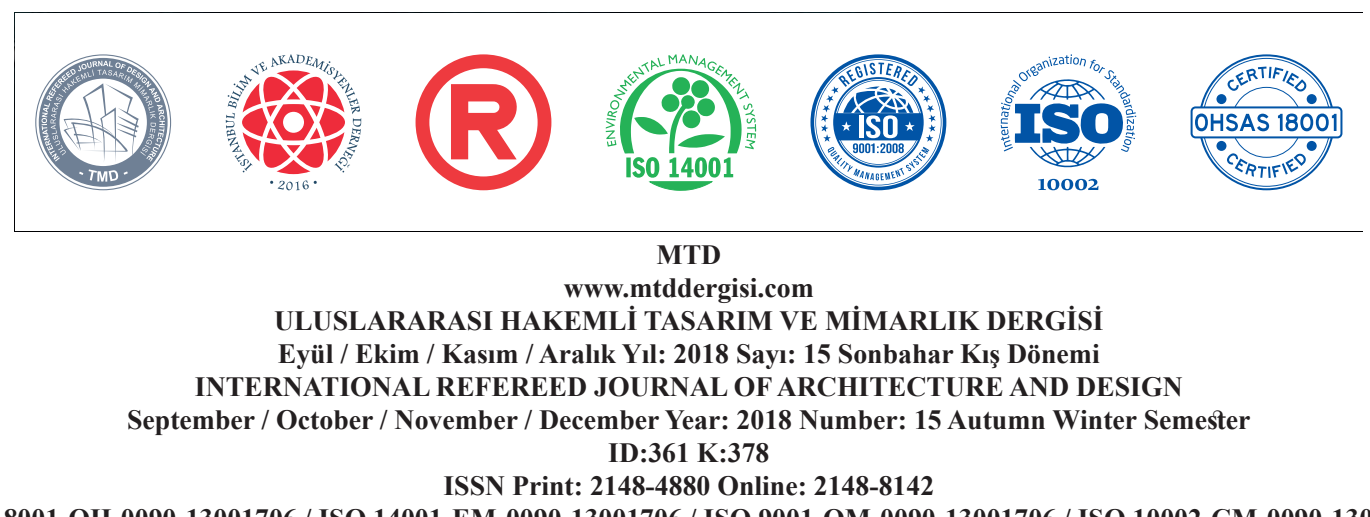

ISSN Print: 2148-4880 Online: 2148-8142

(ISO 18001-OH-0090-13001706 / ISO 14001-EM-0090-13001706 / ISO 9001-QM-0090-13001706 / ISO 10002-CM-0090-13001706)

(Marka Patent No / Trademark)

$(2015 / 04018-2015 /$ GE/17595)

Homesharing model: Having its roots in the USA in 1972, the homesharing was taken up in the early 1980s in Europe. ${ }^{10}$ Several other programmes have later been launched in the USA, Continental Europe (Spain, Netherlands, Germany, and France), UK, Japan, Asia, Canada, Sweden, Norway and Australia to meet urgent need for student accommodation. Homesharing programmes are primarily preferred for the safe environment, constant superintendence and personal reference system they provide. Intergenerational cohabitation has significant positive impacts on the health and morale of elderly individuals. As for the younger individuals, this type of cohabitation provides them with an agreeable and convivial environment as well as financial comfort. ${ }^{11}$

Homeowners, also known as home providers, can be different people having different needs such as high-income earners, persons with disabilities, social workers, persons facing the risk of becoming homeless, single parents or people who just want to share their lives and homes with others. The abovementioned programmes can offer a variety of opportunities, including a shared home, friendship, affordable homes, security, and mutual sup-

the-exchange-the-collective-old-oak-london

10 https://homeshare.org/about-homeshareinternational/the-history-of-homeshare/

11 http://www.lisfrance.org/accompagnement-desporteurs-de-projets/ port, to the intended target group. Homesharing programmes are designed based on the fact that two different people have their own needs and they have different things to offer each other. Homeowners provide accommodation to their homemates in exchange for the help or service they offer. Parties do not pay to each other, all rates or costs are paid to the company that conducts the programme. The services offered by these programmes may be grouped under three headings:

-Services to meet the needs of elderly persons/ persons with disabilities: This is a programme launched to help elderly or elderly individuals continue to happily and independently live in their own homes. Except for providing personal care to elderly persons, the programme is designed to cover and reduce household expenses while it aims to ensure that the elderly individual spends time and socialize with his/ her homemates. Promoting intergenerational solidarity and cooperation, the programme also involves various activities such as simple home repairs, gardening, pet care, medicines management and grocery shopping to keep their homes well-maintained and organized.

-Services to meet student accommodation ne$e d s$ : This programme was designed and developed to provide alternative accommodation and equal opportunities in education to university students. To join the programme, students (aged from 18 to 36 ) are required to 


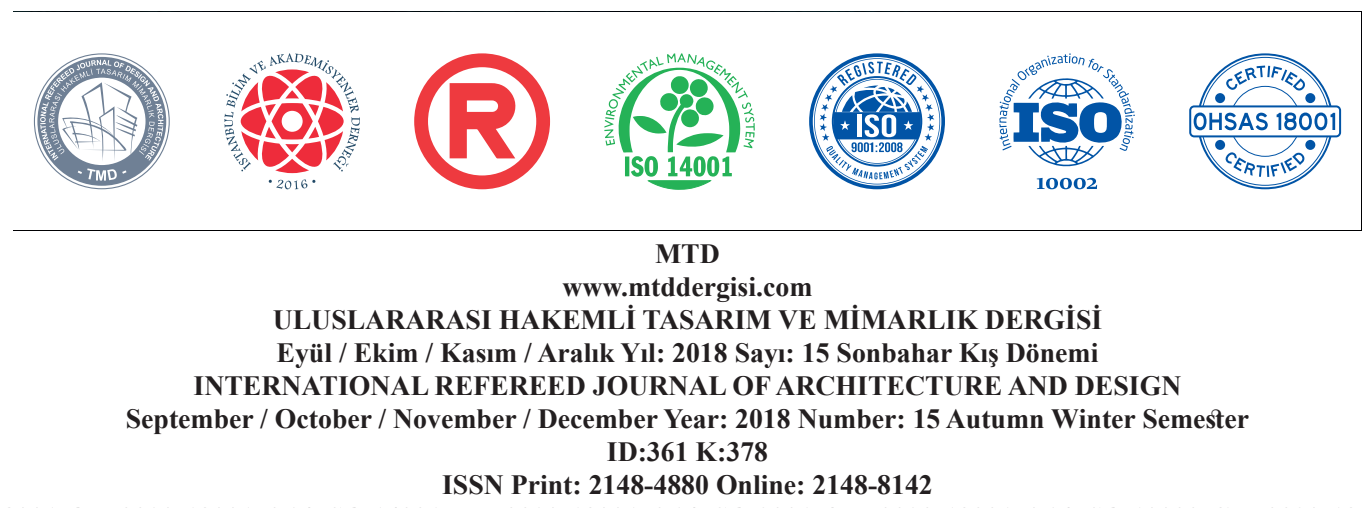

ISSN Print: 2148-4880 Online: 2148-8142

(ISO 18001-OH-0090-13001706 / ISO 14001-EM-0090-13001706 / ISO 9001-QM-0090-13001706 / ISO 10002-CM-0090-13001706)

(Marka Patent No / Trademark)

$(2015 / 04018-2015 / G E / 17595)$

be currently attending a university, have free time to spare, while the elderly homeowners (aged 60 years or over) must meet specific criteria: to be a resident of the chosen neighbourhood, not to be professionally active, to provide sufficient space and a free room in their homes.

- Services to provide an environment of economic and social sharing: In this programme aimed at splitting household expenses, the homeowner/family provides accommodation to a person or persons in exchange for services so they offer. The renter/user can either work for the family, offering services like babysitting, child care, pet care or gardening, or s/he can help pay household expenses without offering a specific service.

\section{RESEARCH METHOD}

Before noting the methods used in this preliminary study, the m:u:t:u:a:1 model which is the subject of this study will be presented below.

m:u:t:u:a:I model (Figure 8) principally suggests a shared living model for elderly individuals living near universities and struggling with loneliness/isolation problems. It aims to meet young individuals' basic physical needs, in this case shelter, when they move to a new city to start a university education. At this point, both subjects tackled by m:u:t:u:a:1 can positively affect each other in order to fulfil the pyramid of needs. Just like the international models of urban co-living examined within this model, which may be built on various patterns such as sharing all units of the house or renting out a specific unit/room, can be based on a shared interests relationship. Today's technologies and new internet trends are causing a rapid increase in poor communication between these two different age groups. Serving as places where different types of individuals gather together until recently, public spaces no longer meet this purpose of helping young and elderly individuals meet/ communicate with each other due to the fact that today's generation of young people do almost everything (bank transactions, shopping etc.) through online platforms. The situation described herein unfortunately brings negative impacts on the continuity of cultural and urban memory in terms of social sustainability.

Basically designed for young and elderly individuals, the m:u:t:u:a:1 also brings value-added ideas to social sustainability. This model essentially puts forward the idea that young individuals' need for accommodation - seen rather as combined problem: the "placelessness" (Arın, 2017:132) issues of students and the "loneliness" problem of elderly individuals - would result in a mutual living beneficial to both age groups. In the m:u:t:u:a:l co-living model, the elderly per- 

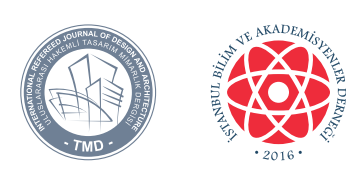

MTD

Www.mtddergisi.com

ULUSLARARASI HAKEMLİ TASARIM VE MIMMARLIK DERGİSì

Eyül / Ekim / Kasım / Aralık Yıl: 2018 Sayı: 15 Sonbahar Kıș Dönemi

INTERNATIONAL REFEREED JOURNAL OF ARCHITECTURE AND DESIGN

September / October / November / December Year: 2018 Number: 15 Autumn Winter Semester ID:361 K:378

ISSN Print: 2148-4880 Online: 2148-8142

(ISO 18001-OH-0090-13001706 / ISO 14001-EM-0090-13001706 / ISO 9001-QM-0090-13001706 / ISO 10002-CM-0090-13001706)

(Marka Patent No / Trademark)

(2015/04018 - 2015/GE/17595)

sons can overcome the challenges of living alone by offering physically capable young individuals a place to live. Aimed at helping both subjects meet the following needs, this model can contribute to the lives of young and elderly individuals,

- Helping young individuals meet their basic physical needs, in this case shelter/ accommodation,

- Providing a safe environment for both subjects (in terms of physical and social safety),
- Enhancing a sense of belonging to the place where both subjects lead a mutual and shared life,

- Helping especially young individuals develop a sense of mutual respect and appreciation so as to help them meet selfesteem needs and learn to appreciate others,

- Contributing to social sustainability by teaching young individuals the activities associated with a social urban culture habits where elderly individuals attain selfactualization.

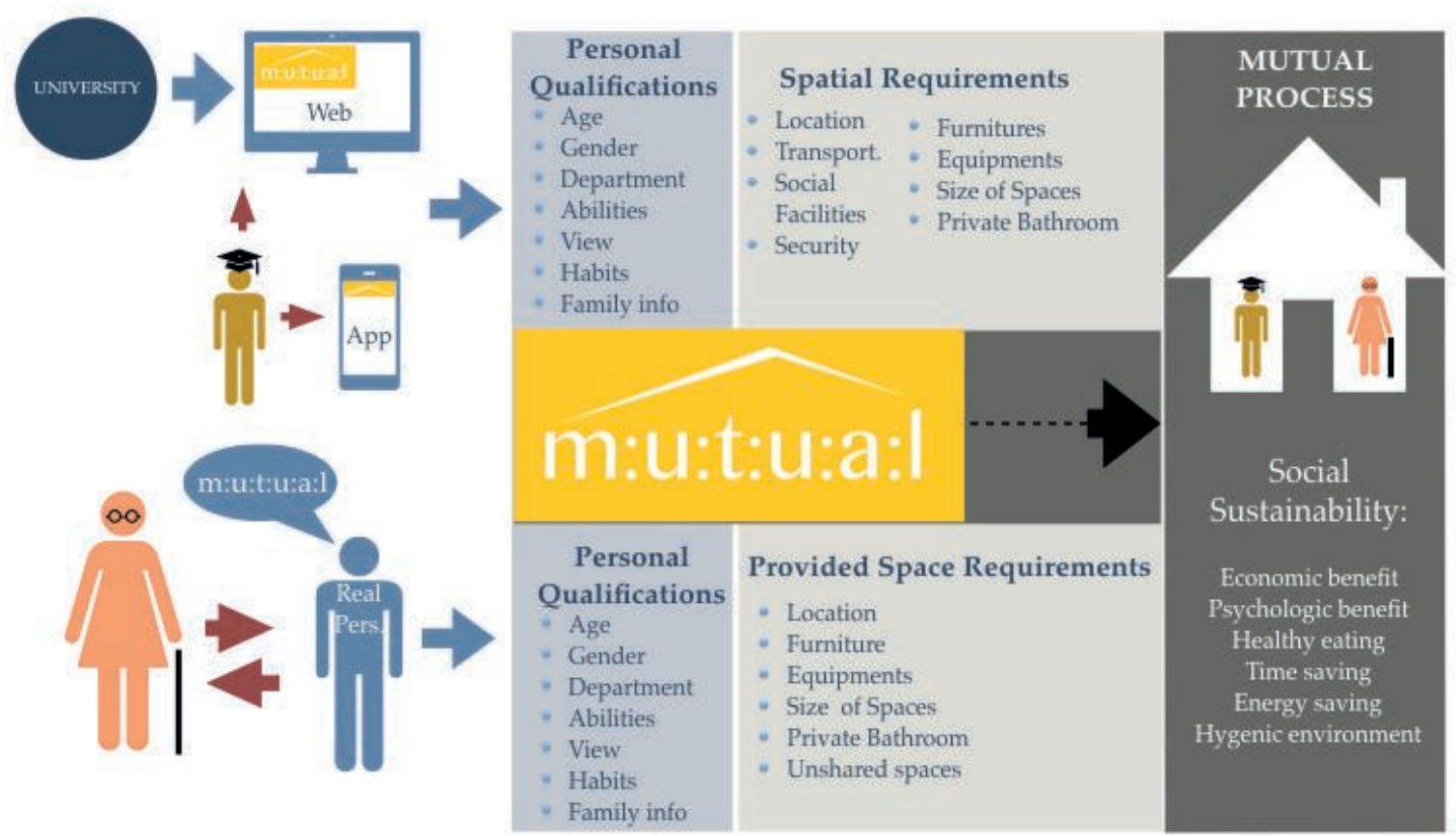

Figure 8. m:u:t:u:a:I : Shared Living Model 


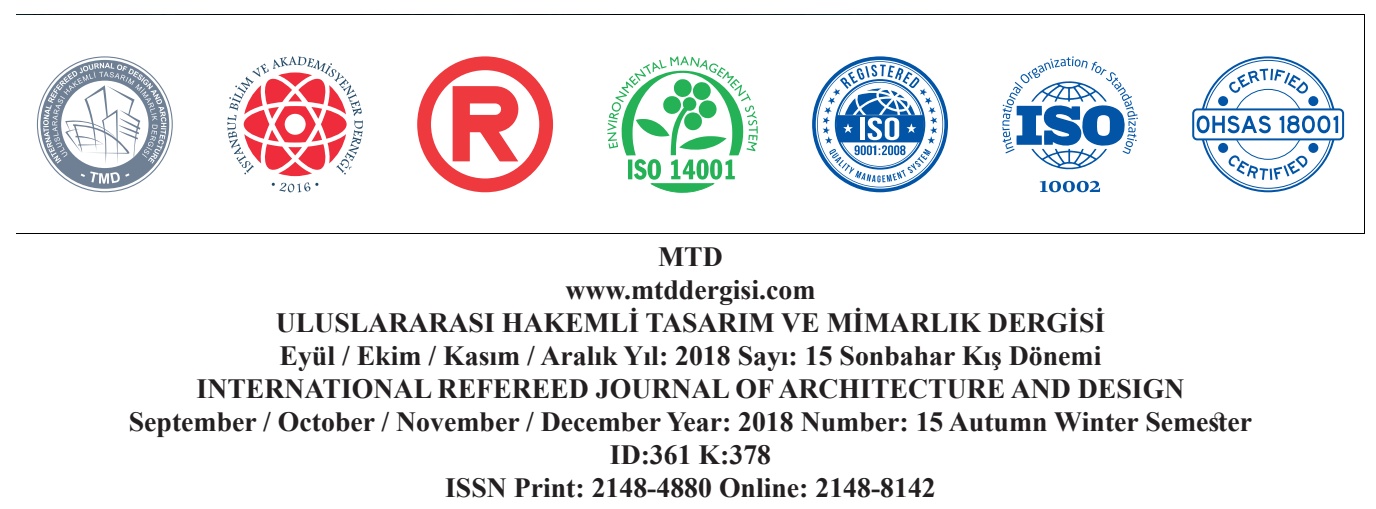

(ISO 18001-OH-0090-13001706 / ISO 14001-EM-0090-13001706 / ISO 9001-QM-0090-13001706 / ISO 10002-CM-0090-13001706)

(Marka Patent No / Trademark)

$(2015 / 04018-2015 / G E / 17595)$

The demand for co-living spaces rapidly increases around the world and the concept of co-living continues to adapt to today's multiple and changing needs enhances the likelihood that people will show interest in the m:u:t:u:a:1 model. However, the thing that makes m:u:t:u:a:1 different from other coliving models is its administrative approach to social sustainability.

This study primarily investigated the capacities of dormitories and the number of university students that attend to the universities located in in Besiktas District; and a comparison is made between the data collected. In addition, a questionnaire is conducted with the 214 university students to measure the their tendencies towards this co-living model. Also, detailed interviews are realized with elderly people to understand their approach.

Within this study, restrictions can be listed as:
- Study group is limited to young individuals (undergraduate architecture students) and elderly (middle-aged and elderly),

- Study area is limited to Beşiktaş District,

- Study covers "housing" as accommodation type.

\section{FINDINGS}

Developed within the scope of this paper, the m:u:t:u:a:1 model was designed to be implemented in Besiktas District of Istanbul. The lack of sufficient and adequate housing has been revealed after a thorough study and analysis of the University campuses located within the borders of Besiktas district (Yildiz Technical University, Istanbul Technical University, Mimar Sinan University of Fine Arts, Galatasaray University, Bahçeşehir University) (Figure 9), the number of students attending these campuses (Table 2), and the housing capacity of nearby private and public dorms.

\begin{tabular}{llllll}
\hline \multicolumn{5}{c}{ Table 2. Total Number of Students Attending Universities in Besiktas District } \\
& $\begin{array}{lllll}\text { Yildiz Technical } \\
\text { Univ. }\end{array}$ & $\begin{array}{l}\text { Mimar Sinan Univ. } \\
\text { of Fine Arts }\end{array}$ & $\begin{array}{l}\text { Istanbul Techni- } \\
\text { cal Univ. }\end{array}$ & Galatasaray & Bahçeşehir \\
$\begin{array}{l}\text { Number of } \\
\text { Students }\end{array}$ & 3515 & 943 & 5748 & Univ. & Univ. \\
\end{tabular}




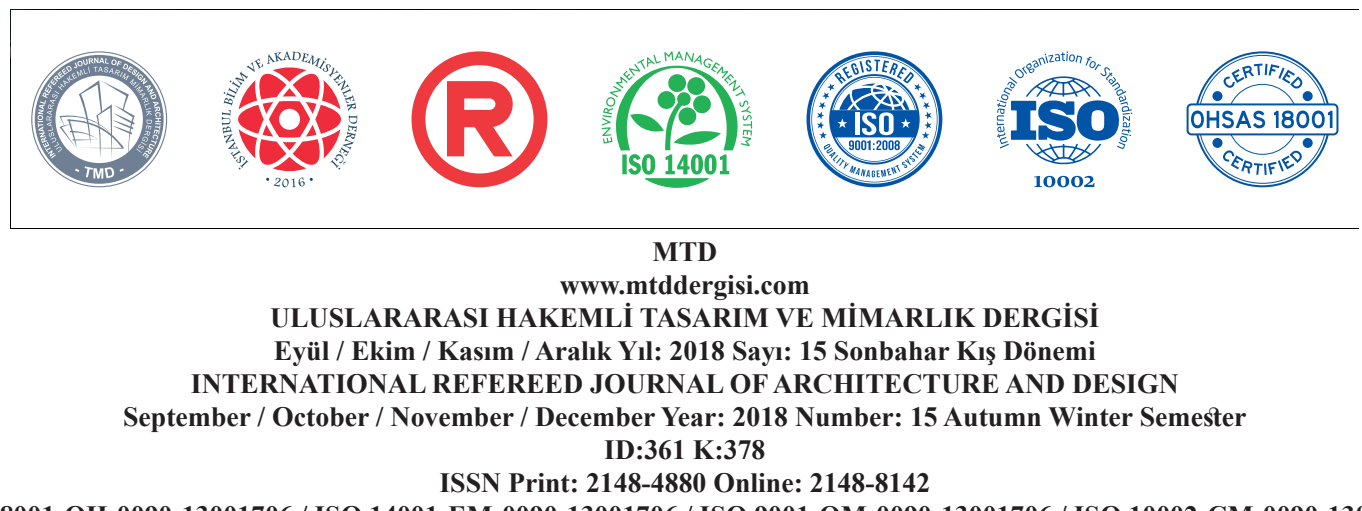

ISSN Print: 2148-4880 Online: 2148-8142

(ISO 18001-OH-0090-13001706 / ISO 14001-EM-0090-13001706 / ISO 9001-QM-0090-13001706 / ISO 10002-CM-0090-13001706)

(Marka Patent No / Trademark)

$(2015 / 04018-2015 / G E / 17595)$

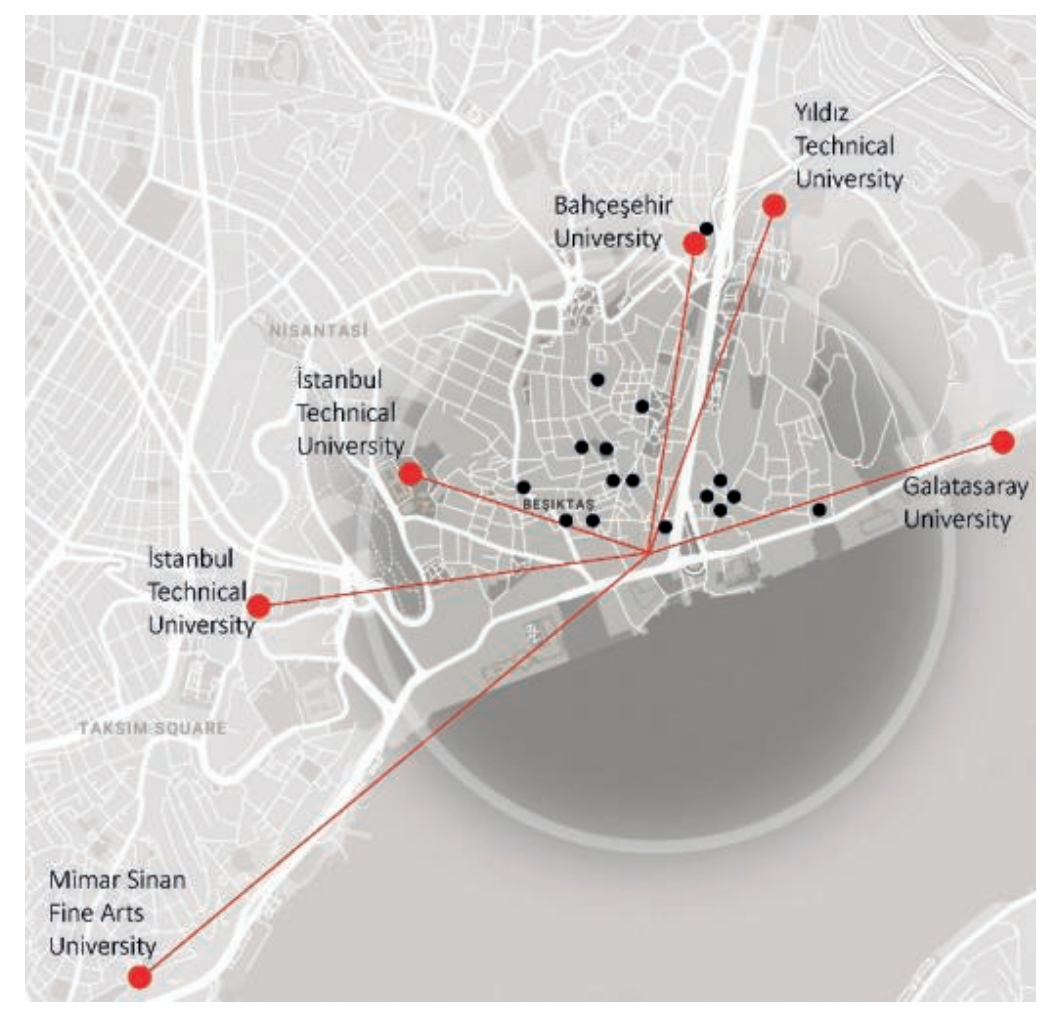

\section{Figure 9. A Map Showing the Distance from Dormitories to Each Campus in Besiktas}

Interviews have been conducted with officers from a total of 21 private and other dorms, owned and managed by the Municipality; 8 out of 21 dorm managements has not provided sufficient data regarding their housing capacity. According to data gathered from 13 dormitories, total student housing capacity in Besiktas is 1093.

Following the interviews, a 10 question-survey aimed at revealing the housing/accommodation practices have been conducted with 214 architecture students from Yildiz Technical University. The results from this site study have shown the applicability of the m:u:t:u:a:1 model. It is envisaged to establish cooperation with sharehelderlys and seek funding so that the project/model can be put into practice in the future.

A 10-question online survey has been conducted to analyse students' own living practices and find out their opinions on the concept of co-living. Undergraduate, master's and $\mathrm{PhD}$ degree students from Yildiz Technical University (YTU) Architecture program took the survey (a total of 118 female and 95 male participants). A total of 30 first-year students, 


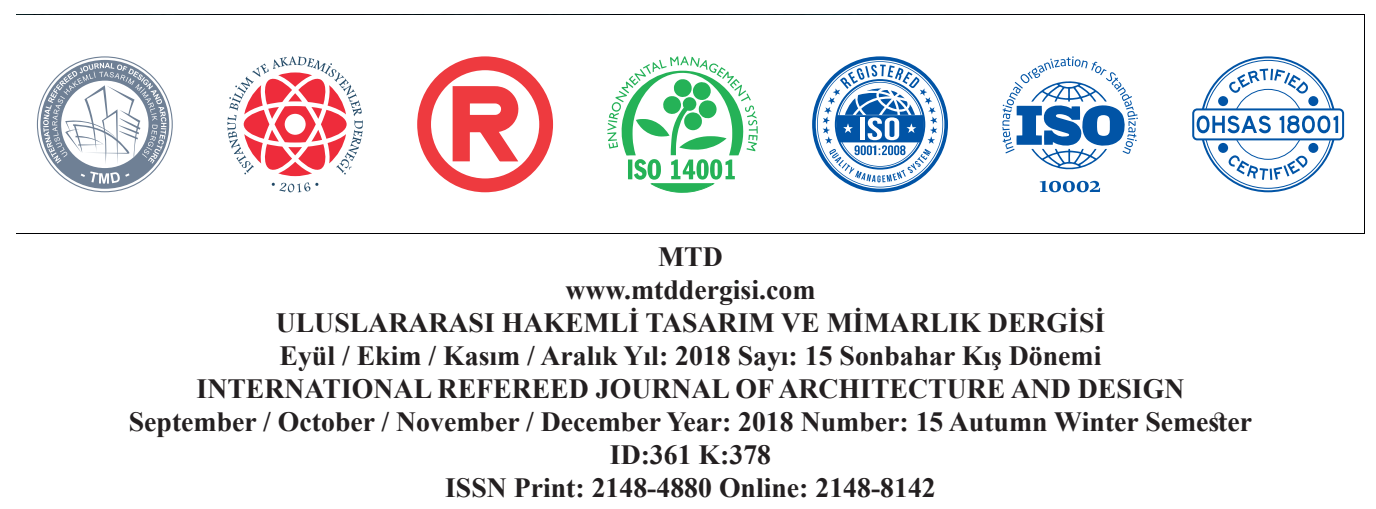

(ISO 18001-OH-0090-13001706 / ISO 14001-EM-0090-13001706 / ISO 9001-QM-0090-13001706 / ISO 10002-CM-0090-13001706)

(Marka Patent No / Trademark)

$(2015 / 04018-2015 / G E / 17595)$

105 second-year students, 25 third-year students and again 25 fourth-year students have participated in the survey. The number of master's degree and $\mathrm{PhD}$ degree participants respectively are 16 and 13 .

The answers provided to the question, which was designed to identify students' places of residence, have revealed that $30,5 \%$ of them live in or in the vicinity of Besiktas District, followed by Kadikoy/Uskudar (23\%), YTU Davutpasa campus (17\%), Mecidiyeköy/ Gayrettepe area (13\%) and other neighbourhoods (16,5\%) (Figure 10) It was concluded

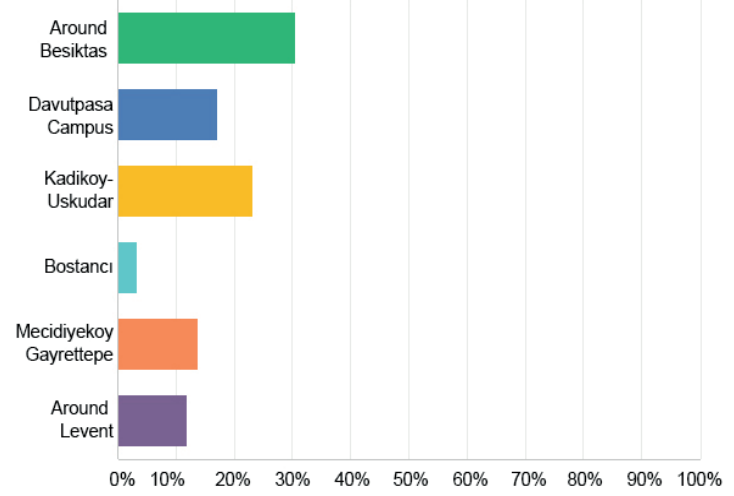

that participants prefer more central and convenient neighbourhoods with public transport connections to other parts of the city. However, the reason why students mostly prefer to live in Besiktas District is because it is conveniently located close to campuses (walking distance). When asked about their living habits and practices, it has been seen that 29,6\% of students live with a housemate, followed by multi-person dorm room $(29 \%)$, and the rest of them answered that they live in their own homes with the family $(28,2 \%) .8 \%$ of the students, on the other hand, live alone (other 5,2\%) (Figure 10)

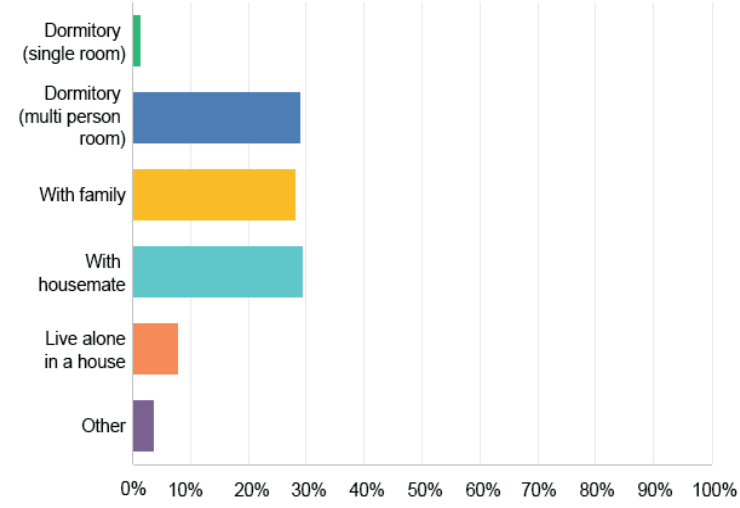

Figure 10. (left) Housing Districts of Students, (right) Preference of Housing Types

With regard to monthly rental charges, the study has revealed that $26 \%$ of students pay a monthly rent of TRY 1000 and above (Graphic 2). While $24 \%$ of students stated that they do not incur housing expenses; 9,5\% said they spend TRY 800-999/month on housing costs, $16 \%$ of them pay TRY $600-799 /$ month, $6 \%$ pay TRY 400-599/month and the rest (18\%) stated their monthly housing expenses are around TRY 0-400. When we analyse and interpret the survey results, we can say that most students prefer co-living or shared 


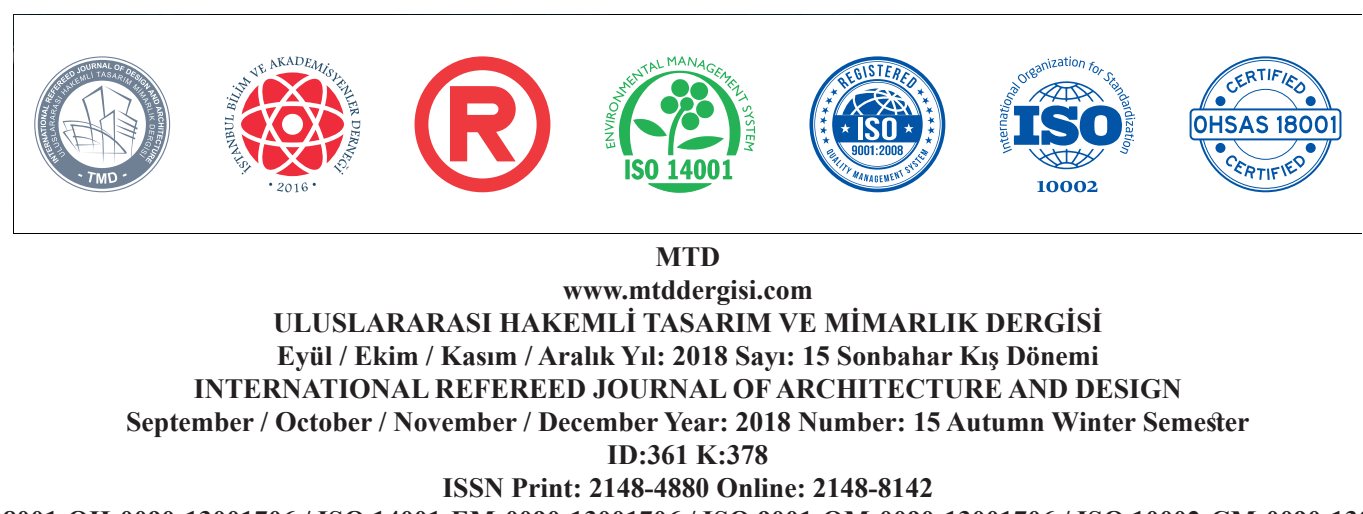

ISSN Print: 2148-4880 Online: 2148-8142

(ISO 18001-OH-0090-13001706 / ISO 14001-EM-0090-13001706 / ISO 9001-QM-0090-13001706 / ISO 10002-CM-0090-13001706)

(Marka Patent No / Trademark)

$(2015 / 04018-2015 / G E / 17595)$

accommodation in a major city like Istanbul with high cost of living.

When asked about the time they spend travelling to campus, $44,4 \%$ of students replied that it takes approximately 30-59 minutes to get to

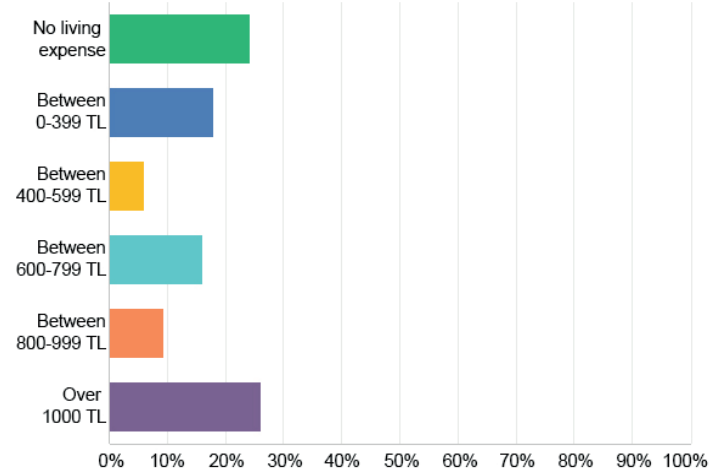

campus, followed by 15-29 minutes (23\%), less than 15 minutes $(13,7 \%)$ and more than 60 minutes of travel (18,5\%) (Figure 11) This result reveals that students mostly prefer expensive neighbourhoods yet providing relatively easy access to public transportation.

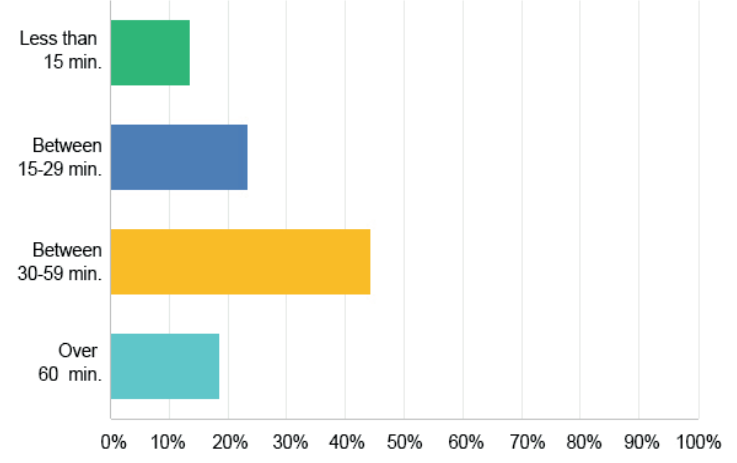

Figure 11. (left) Monthly Living Expenses, (right) Time Spend to Travel to Campus.

When asked about the types of transport they prefer to get to campus, students were allowed to give multiple responses. Accordingly, $82,9 \%$ of students indicated they prefer to travel by bus, followed by walking (31\%), travel by metrobus $(28 \%)$, by ferry $(25,6 \%)$ and subway travel $(23,2 \%)$ The result shows that students are using multiple types of public transport (Figure 12).
When asked "What kind of life would you prefer?", 37\% of students answered that they prefer to live alone, followed by living with housemates $(32,7 \%)$, and living with family $(26,4 \%)$. Accordingly, the fact that the remaining 3,9\% choose to live in university dormitories shows that students prefer a cosy and pleasant atmosphere at home rather than stay at a dorm room (Figure 12). 


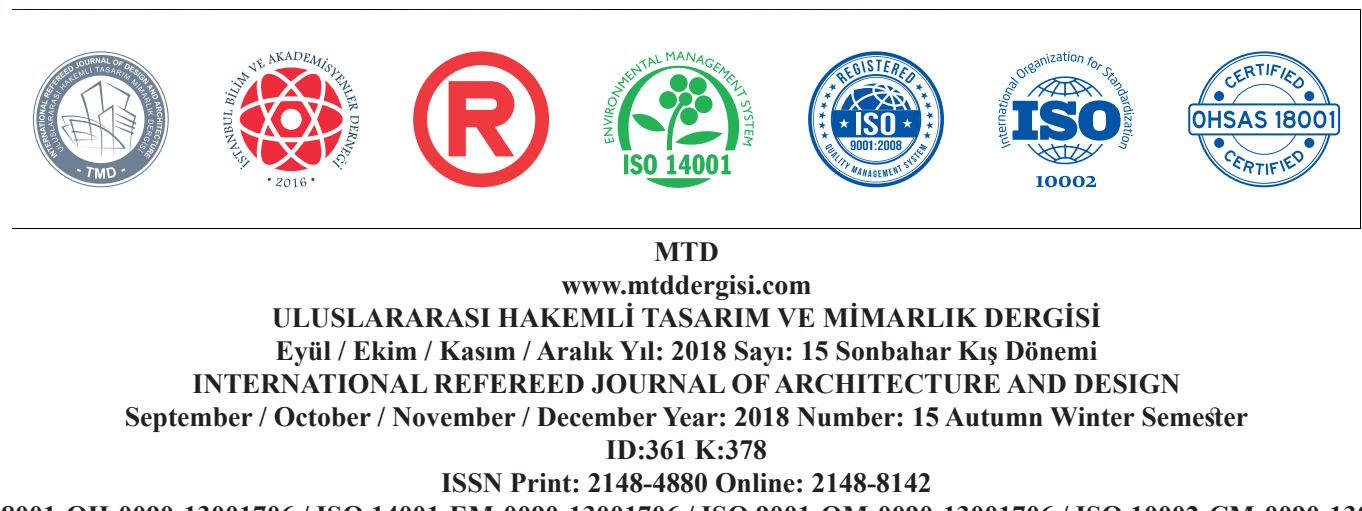

ISSN Print: 2148-4880 Online: 2148-8142

(ISO 18001-OH-0090-13001706 / ISO 14001-EM-0090-13001706 / ISO 9001-QM-0090-13001706 / ISO 10002-CM-0090-13001706)

(Marka Patent No / Trademark)

$(2015 / 04018-2015 / G E / 17595)$
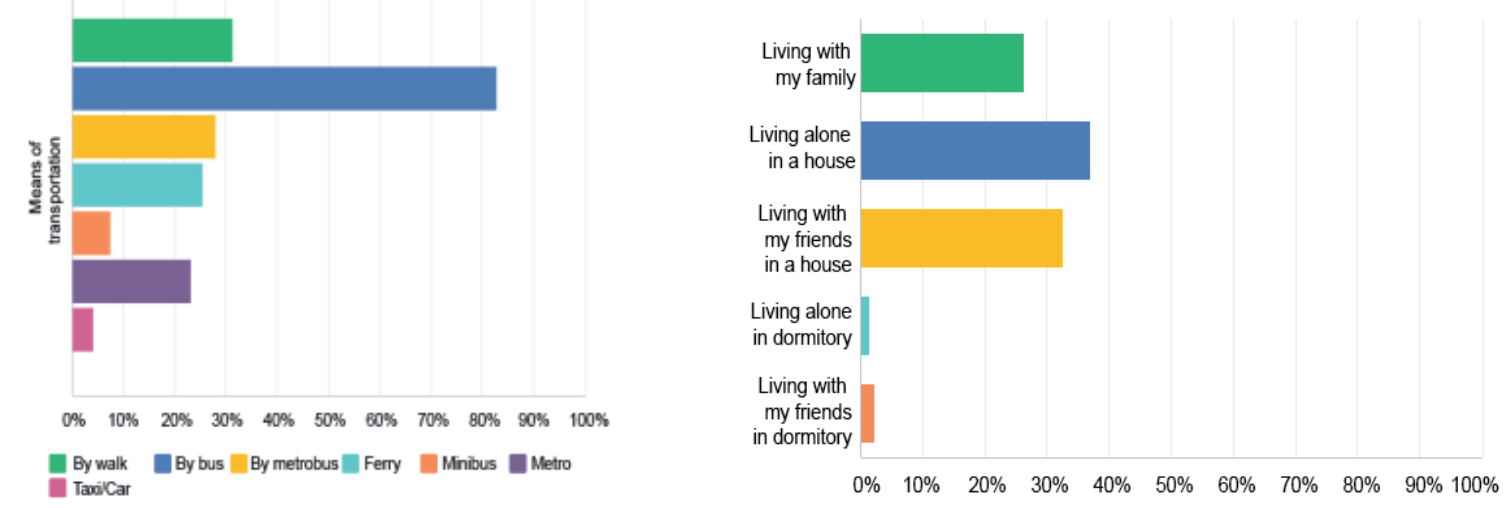

Figure 12. (left) Preference of Transportion Type, (right) Results of Living Preference of Students

Lastly, when asked "Would you live with an be provided with good living conditions?" elderly person in his/her house conveniently $58,9 \%$ of students seemed to welcome the located near your campus, where you will idea (Figure 13).

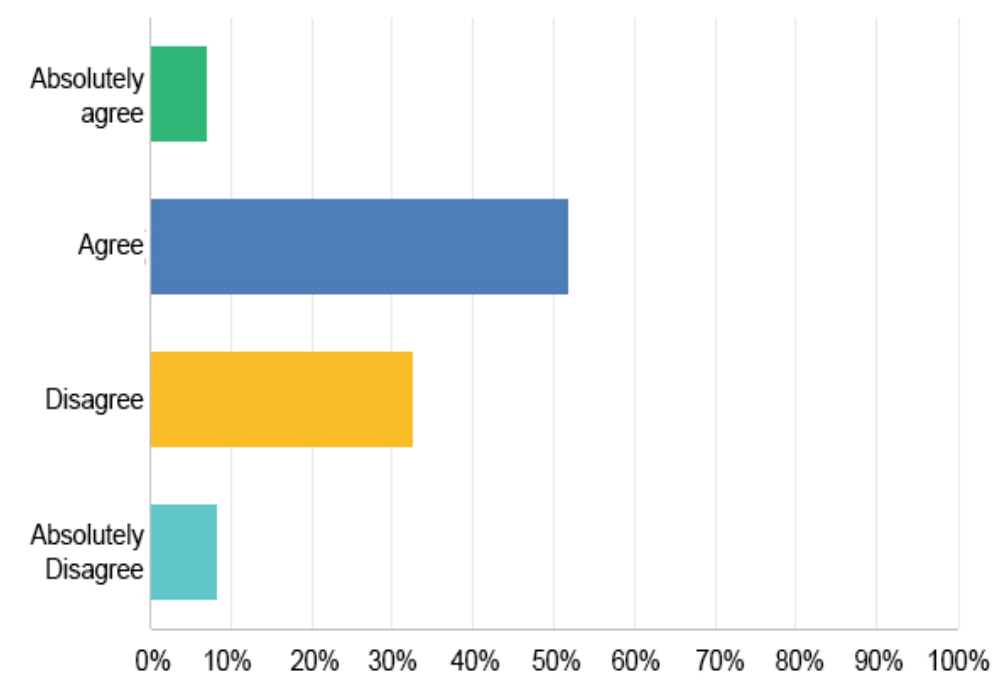

Figure 13. Answers Given to the Preference of a Living Model with a Elderly Person in a Convenient Location with Good Living Conditions

When students were asked about their general derline the importance of setting boundaries opinions on the project, they especially un- and feeling a sense of security when sharing 


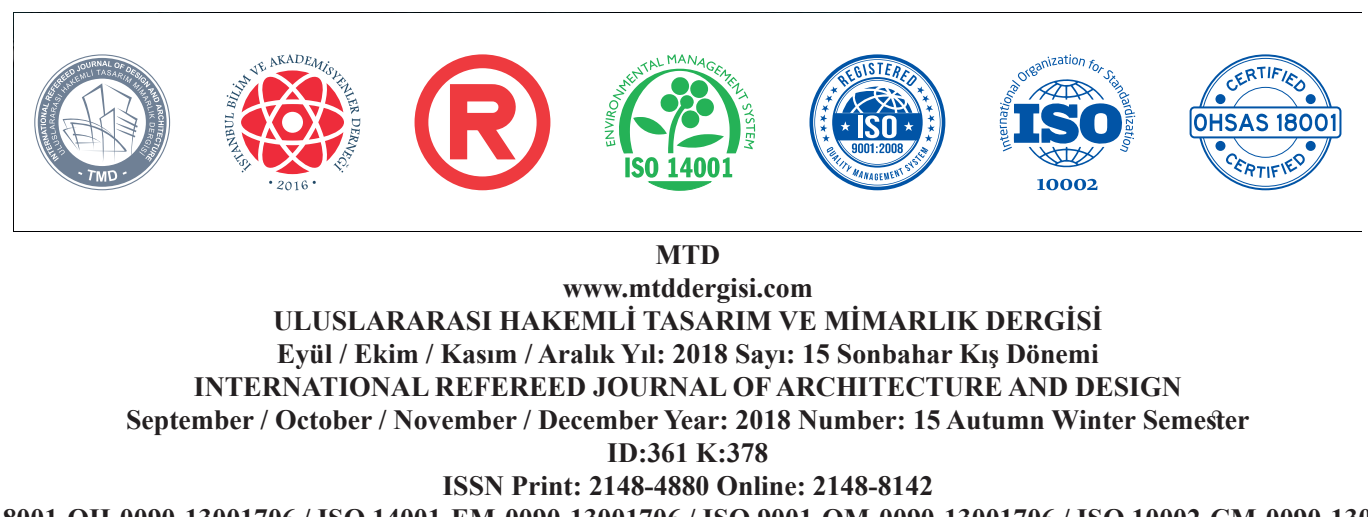

ISSN Print: 2148-4880 Online: 2148-8142

(ISO 18001-OH-0090-13001706 / ISO 14001-EM-0090-13001706 / ISO 9001-QM-0090-13001706 / ISO 10002-CM-0090-13001706)

(Marka Patent No / Trademark)

$(2015 / 04018-2015 /$ GE/17595)

a house with an elderly person. The survey revealed that students would want elderly individuals to be capable of meeting their own needs and to avoid interfering with students' personal lives and living spaces. According to one student, however, living with a person with more life experience than himself/herself and having a chance to live near campus and public transportation could have a lot of benefits.

According to another student, on the other hand, it is essential that the expectations of the elderly individuals who volunteer for the project and the expectations of students should be based on a win-win relationship and mutual benefits, as both parties can learn a lot from each other.

Besides the research of student's opinions, elderly's approaches are also investigated by detailed interviews. In these interviews, 50/ 60 -year-old people is questioned who is living alone in Beşiktaş.

The aim of the interviews is especially to find out the opinions of elderly user's co-living ideas and experiences of their lives. The collective beliefs and the risks for the proposed model are;

- A trial period of one week should be spend with the young person,
- Hosting time should be limited up to 4 months (a term), after this time an interview should be done between two people.

- Housekeeping service should be provided weekly,

- A private bathroom should be provided for each user

In summary, both students and elderly have considered the project quite beneficial in terms of sharing experience and expenses; by helping student's families out financially, being an alternative option to expensive university dorms and expensive rental homes.

\section{CONCLUSION}

Households today are evolving into new forms due to dynamic life circumstances and vastly diversified social structures. Students moving to large cities to seek higher education and elderly individuals, who become lonelier with the transition from the extended to nuclear and single-parent families, have started to create alternative forms in household typology. Attempting to design sharing economy-based new co-living models for both groups that are trying to survive within changing economic and social dynamics can be useful in terms of providing solutions to cover the shortcomings of the abovementioned new typologies in various scales. In this context, the scope of this study, which covers 


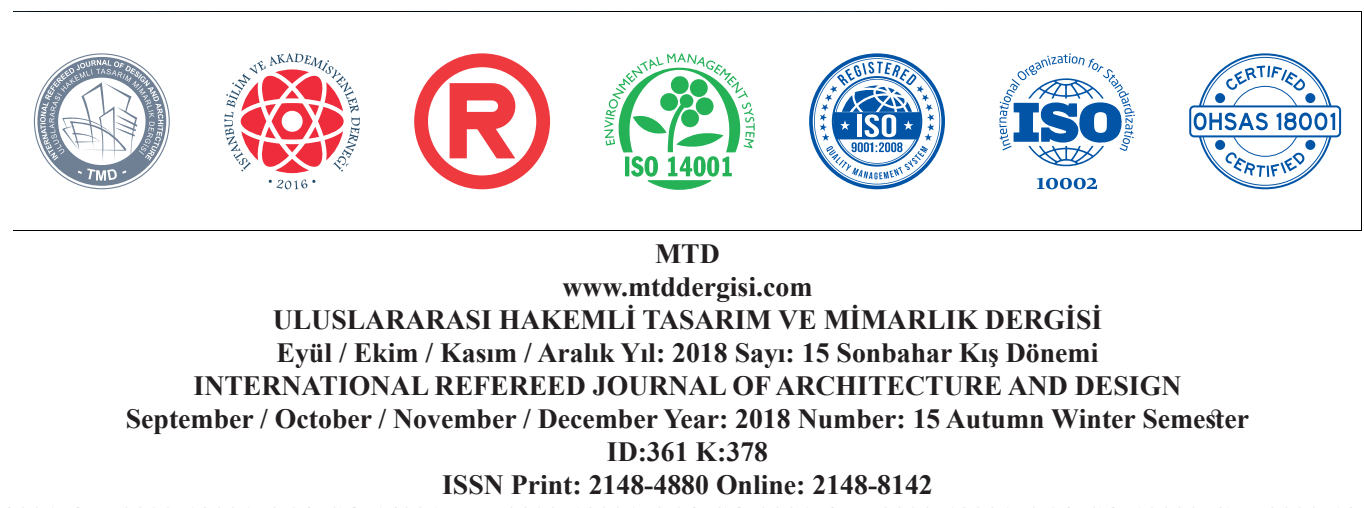

ISSN Print: 2148-4880 Online: 2148-8142

(ISO 18001-OH-0090-13001706 / ISO 14001-EM-0090-13001706 / ISO 9001-QM-0090-13001706 / ISO 10002-CM-0090-13001706)

(Marka Patent No / Trademark)

$(2015 / 04018-2015 / G E / 17595)$

the various examples of shared economy practices and co-living models that have been implemented since the 1970's, offers perspectives on the applicability of similar models in Turkey.

In this paper, first, the m:u:t:u:a:1 model that aims to establish a mutually beneficial relationship between the university students and elderly individuals living alone in urban areas was introduced. In order to test the user tendencies towards such a co-living suggested in the model, a preliminary study is conducted in Besiktas District of Istanbul. A questionnaire is realized with university students that aims to measure the neeeds and preferences of them on co-living ideas suggested in m.u.t.u.a.l model. In addition, to understand the current condition about accommodation alternatives of university students in Besiktas district, capacities of dormitories are determined. Also, interviews with elderly people supported the measurements for the model. Based on the case study findings, a comparison carried out between the number of students attending campuses in Besiktas and the housing capacity of nearby dormitories has revealed the lack of campus housing capacity. The results of the questionnaire reveal that most of the university students seem to welcome the idea of living with elderly individuals. Elderly people also welcome the idea of co-living and they offered improvements for the model. It is envisaged to conduct further site studies and surveys, researches to test the applicability of the m:u:t:u:a:1 model.

\section{REFERENCES}

$A K S U, C$., (2011). Sürdürülebilir Kalkınma ve Çevre, Güney Ege Kalkınma Ajansı, ss. 12

ARIN, S., (2017). "Non-place" Under the Domination of Control Mechanisms. International Refereed Journal of Design and Architecture, 10: 132-145. Doi: 10.17365/TMD.2017.1.010.x

BASIAGO, A.D., (1999). Economic, Social, and Environmental Sustainability in Development Theory and Urban Planning Practice. The Environmentalist, 19: 145161

BRANDE, K.V., (2012). The European Union in the Commission on Sustainable Development, In: The European Union and Multilateral Governance, Palgrave Studies in European Union Politics, Palgrave Macmillan, London, p.172

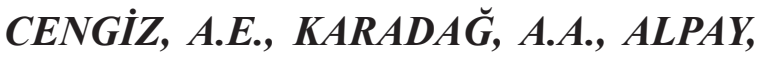
C.O., (2014), An Environmentally Friendly Type of Building: Green buildings, International Refereed Journal of Design and Architecture, 1(1): 24-31. Doi: 10.17365/TMD.2014019185 


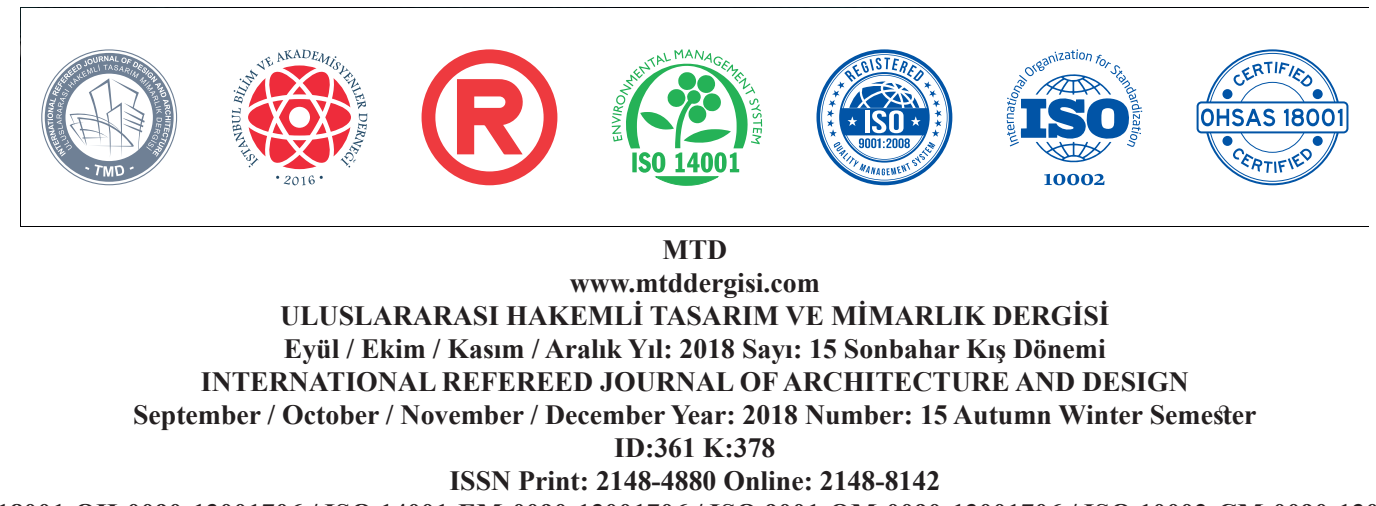

ISSN Print: 2148-4880 Online: 2148-8142

(ISO 18001-OH-0090-13001706 / ISO 14001-EM-0090-13001706 / ISO 9001-QM-0090-13001706 / ISO 10002-CM-0090-13001706)

(Marka Patent No / Trademark)

$(2015 / 04018-2015 / G E / 17595)$

DEMIRER, D., HASSAN, A., (2016). Değiş Tokuş ve Kiralama Uygulamalarının Konaklama İşletmeleri Üzerindeki Olası Etkileri, Anatolia: Turizm Araştırmaları Dergisi, 27(1): 43-61.

EKINS, P., (1993). Limits to Growth' and 'Sustainable Development': Grappling with Ecological Realities, Ecological Economics, 8 (3): 269-288.

GÜREL ÜÇER, Z.A., (2017). Kentsel Politikaların Belirlenmesinde Bir Araç: Sürdürülebilirlik Göstergeleri, Çağdaş Yerel Yönetimler Dergisi, 26 (1): 103-124.

HOLDEN, E., LINNERUD, K., BANNISTER, D., (2014). Sustainable Development: Our Common Future Revisited, Global Environmental Change, 26: 130139.

KESSLER, W., SALWASSER, H., CARTWRIGHT, C., CAPLAN, J., (1992). New Perspectives for Sustainable Natural Resources Management, Ecological Applications, 2 (3): 221-225.

KOÇ, Ç., SÖNMEZ, M., (2017). The Architect of Today on the Edge of Chaos; An Approach through Chaos Theory, Gazi University Journal of Science Part B: Art, Humanities, Design and Planning, 30(1):1-7.
KURTASLAN, B.Ö., (2014). Kentsel Yeşil Yollar ve Sürdürülebilirlik: Boston Rose Fitzgerald Kennedy Yeşil Yolu Örneği, International Refereed Journal of Design and Architecture, 2(1): 86-97. Doi: 10.17365/TMD.201429189

LANGHELLE, O., (1999). Sustainable Development: Exploring the Ethics of Our Common Future, International Political Science Review, 20 (2): 129-149.

MASLOW, A.H., (1943). A Theory of Human Motivation, Psychological Review, 50, p. 370-396.

PASSET, R., (1979). L'Economique et le vivant (in French), Payot, p. 10-11

SEGHEZZO, L., (2009). The Five Dimensions of Sustainability, Environmental Politics, 18 (4): 539-556.

YENI, O., (2014). Sürdürülebilirlik ve Sürdürülebilir Kalkınma: Bir Yazın Taramas1, Gazi Üniversitesi İktisadi ve İdari Bilimler Fakültesi Dergisi, 16(3):181-208.

\section{INTERNET REFERENCES}

https://tr.pinterest.com/ pin/363032419942229925/ (E.T. 15.04.2018)

http://www.ukayamut.com/wp-content/ uploads/2016/02/the-sharing-economy- 


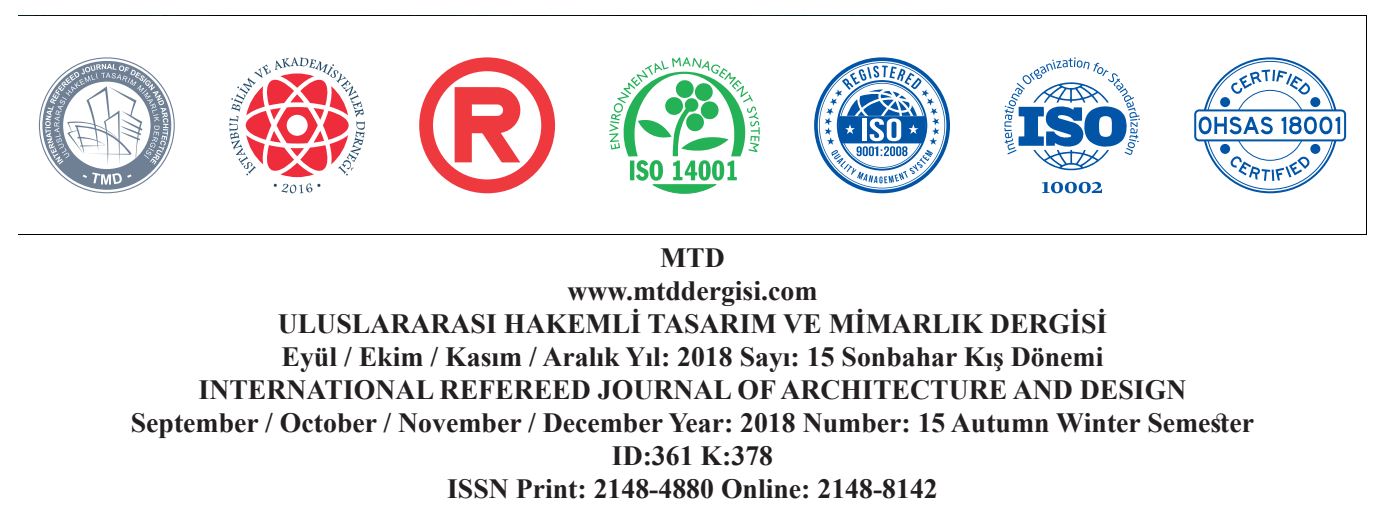

ISSN Print: 2148-4880 Online: 2148-8142

(ISO 18001-OH-0090-13001706 / ISO 14001-EM-0090-13001706 / ISO 9001-QM-0090-13001706 / ISO 10002-CM-0090-13001706)

(Marka Patent No / Trademark)

(2015/04018 - 2015/GE/17595)

and-sustainability-feb-7-2016.pdf (E.T. 15.04.2018)

https://www.greenamerica.org/go-green-

budget/10-ways-join-sharing-economy

(E.T. 15.04.2018)

https://esa.un.org/unpd/wup/ (E.T.

17.04.2018)

http://design-planning.blogspot.com.

tr/2017/11/exhibit-new-american-

households.html (E.T. 13.03.2018)

https://www.thecollective.co.uk/coliving

(E.T. 13.04.2018)

https://www.dezeen.com/2016/07/15/in-the-

future-we-will-all-be-homeless-says-

co-living-entrepreneur-the-collective-

james-scott-housing/ (E.T. 13.04.2018)

https://www.headbox.com/spaces/6444-

book-the-exchange-the-collective-old-

oak-london (E.T. 13.04.2018) https://www.independent.co.uk/life-style/ health-and-families/why-some-dutchuniversity-students-are-living-innursing-homes-demential-a7451486. html (E.T. 13.04.2018)

https://homeshare.org/about-homeshare-international/the-history-of-homeshare/ (E.T.13.04.2018)

http://www.lisfrance.org/accompagnementdes-porteurs-de-projets/ (E.T. 10.04.2018)

https://yokatlas.yok.gov.tr/(E.T. 20.04.2018)

https://www.nbm.org/exhibition/making-room/ (E.T. 20.04.2018)

Authors' Note: This study has been presented in "1. Istanbul Konut Kurultayl" between 10-11 Mav 2018 with the title "Sosval Sürdürülebilirlik BağlamındaAlternatif Yaklasımlar: Yaslı ve Genc Bireylerin OrtakBarınma Pratikleri" in Istanbul. 